\title{
Review \\ Review of Ceftazidime-Avibactam for the Treatment of Infections Caused by Pseudomonas aeruginosa
}

\author{
George L. Daikos ${ }^{1, *}$, Clóvis Arns da Cunha ${ }^{2}$, Gian Maria Rossolini ${ }^{3,4}$, Gregory G. Stone ${ }^{5}$, Nathalie Baillon-Plot ${ }^{6}$, \\ Margaret Tawadrous ${ }^{5}$ and Paurus Irani ${ }^{7}$ \\ 1 Department of Medicine, National and Kapodistrian University of Athens, 115-27 Athens, Greece \\ 2 Hospital Nossa Senhora das Graças, Curitiba 80810-040, PR, Brazil; arnscunha@gmail.com \\ 3 Department of Experimental and Clinical Medicine, University of Florence, I-50134 Florence, Italy; \\ gianmaria.rossolini@unifi.it \\ 4 Clinical Microbiology and Virology Unit, Careggi University Hospital, I-50134 Florence, Italy \\ 5 Pfizer, Groton, CT 06340, USA; GregoryG.Stone@pfizer.com (G.G.S.); margaret.tawadrous@pfizer.com (M.T.) \\ 6 Pfizer, CEDEX 14, 75688 Paris, France; nathalie.Baillon-Plot@pfizer.com \\ 7 Pfizer, Tadworth, Surrey KT20 7NS, UK; Paurus.Irani@pfizer.com \\ * Correspondence: gldaikos@gmail.com; Tel.: +30-210-804-9218
}

Citation: Daikos, G.L.; da Cunha, C.A.; Rossolini, G.M.; Stone, G.G.; Baillon-Plot, N.; Tawadrous, M.; Irani, P. Review of Ceftazidime-Avibactam for the Treatment of Infections Caused by Pseudomonas aeruginosa. Antibiotics 2021, 10, 1126. https:// doi.org/10.3390/antibiotics10091126

Academic Editor: Giovanna Batoni

Received: 9 July 2021

Accepted: 16 September 2021

Published: 18 September 2021

Publisher's Note: MDPI stays neutral with regard to jurisdictional claims in published maps and institutional affiliations.

Copyright: (c) 2021 by the authors. Licensee MDPI, Basel, Switzerland. This article is an open access article distributed under the terms and conditions of the Creative Commons Attribution (CC BY) license (https:/ / creativecommons.org/licenses/by/ $4.0 /)$.

\begin{abstract}
Pseudomonas aeruginosa is an opportunistic Gram-negative pathogen that causes a range of serious infections that are often challenging to treat, as this pathogen can express multiple resistance mechanisms, including multidrug-resistant (MDR) and extensively drug-resistant (XDR) phenotypes. Ceftazidime-avibactam is a combination antimicrobial agent comprising ceftazidime, a thirdgeneration semisynthetic cephalosporin, and avibactam, a novel non- $\beta$-lactam $\beta$-lactamase inhibitor. This review explores the potential role of ceftazidime-avibactam for the treatment of $P$. aeruginosa infections. Ceftazidime-avibactam has good in vitro activity against $P$. aeruginosa relative to comparator $\beta$-lactam agents and fluoroquinolones, comparable to amikacin and ceftolozane-tazobactam. In Phase 3 clinical trials, ceftazidime-avibactam has generally demonstrated similar clinical and microbiological outcomes to comparators in patients with complicated intra-abdominal infections, complicated urinary tract infections or hospital-acquired/ventilator-associated pneumonia caused by P. aeruginosa. Although real-world data are limited, favourable outcomes with ceftazidime-avibactam treatment have been reported in some patients with MDR and XDR P. aeruginosa infections. Thus, ceftazidime-avibactam may have a potentially important role in the management of serious and complicated P. aeruginosa infections, including those caused by MDR and XDR strains.
\end{abstract}

Keywords: ceftazidime-avibactam; Pseudomonas aeruginosa; multidrug resistance; complicated intraabdominal infection; complicated urinary tract infection; hospital-acquired pneumonia

\section{Introduction}

Pseudomonas aeruginosa is an opportunistic Gram-negative pathogen responsible for approximately $5-14 \%$ of all nosocomial or healthcare-associated infections and $16-40 \%$ of cases of ventilator-associated pneumonia (VAP) [1-5]. Patients with predisposing factors, such as severe burn victims, those with reduced immune function and those admitted to the intensive care unit (ICU), are at increased risk of acute $P$. aeruginosa infections; patients with cystic fibrosis (CF) or bronchiectasis may also develop chronic or recurrent $P$. aeruginosa infections [5-9]. While the reported extent of co-infection with bacterial pathogens in patients hospitalized with COVID-19 varies, $P$. aeruginosa is among the most frequently identified species in such patients, with a higher proportion in critically ill ICU patients [10]. Moreover, ventilated patients with COVID-19 may be at higher risk of developing VAP, with $P$. aeruginosa accounting for a high proportion of cases [11]. 
P. aeruginosa infections are often life-threatening and can be difficult to treat because these bacteria can express numerous acquired antimicrobial resistance mechanisms, virulence factors and mechanisms for evading host defences (including biofilm formation) [12-14]. Increasing antimicrobial resistance among $P$. aeruginosa (partly due to inappropriate antibiotic use) includes de novo development of resistance attributable to complex interactions between multiple adaptive cellular mechanisms and DNA mutations [15-18]. Healthcare practices continue to impact resistance profiles; it has been reported that global antimicrobial usage has surged during the COVID-19 pandemic, and there is concern about the impact this will have on resistance rates, particularly in ICUs, where P. aeruginosa is most problematic $[19,20]$.

Antibiotics commonly used for $P$. aeruginosa infections include anti-pseudomonal cephalosporins, carbapenems, $\beta$-lactam / $\beta$-lactamase inhibitor combinations, fluoroquinolones, aminoglycosides and polymyxins [21]. Progressive accumulation of antibiotic resistance mechanisms may result in multidrug-resistant (MDR) and extensively drug-resistant (XDR) phenotypes of $P$. aeruginosa [8,12]. Although epidemiologically useful, the bedside applicability of MDR and XDR definitions is limited, as their definitions require resistance to only one agent per antimicrobial category, and all antibiotics are weighted equally regardless of effectiveness and toxicity [22]. Consequently, difficult-to-treat resistance (DTR), defined as in vitro resistance to all first-line agents, has been proposed to describe antimicrobial resistance in Gram-negative bacteria [22]. P. aeruginosa was the most frequently identified DTR pathogen (accounting for $38.1 \%$ of 1371 episodes) in a recent retrospective review of Gram-negative infections in US hospitals [23]. The development of MDR and DTR P. aeruginosa is of particular concern for public health and highlights the need for novel therapeutics to treat $P$. aeruginosa infections $[8,12,24]$.

Ceftazidime-avibactam is a combination antimicrobial agent comprising ceftazidime (an extended-spectrum, third-generation, semisynthetic anti-pseudomonal cephalosporin) and avibactam (a novel non- $\beta$-lactam $\beta$-lactamase inhibitor) [25-28]. Ceftazidime has broad in vitro activity against Gram-negative aerobic bacteria, including P. aeruginos $a$ and Enterobacterales [29]. However, the utility of third-generation cephalosporins has become compromised by the increasing prevalence of MDR Gram-negative bacteria, including those producing extended-spectrum $\beta$-lactamases (ESBLs), chromosomal AmpC cephalosporinases, Klebsiella pneumoniae carbapenemases (KPCs) and metallo- $\beta$-lactamases (MBLs) [30]. Avibactam restores the in vitro activity of ceftazidime against bacteria expressing Ambler class A (e.g., ESBLs and KPCs), class C (e.g., AmpC cephalosporinases), including some that co-express class D (e.g., oxacillinase- 48 ) $\beta$-lactamases, but not against those that produce MBLs $[25,26,30]$. Ceftazidime-avibactam is active in vitro against many MDR, ceftazidime-non-susceptible and carbapenem-resistant $P$. aeruginosa strains [31-34].

This mini-review explores the potential role of ceftazidime-avibactam in the management of $P$. aeruginosa infections.

\section{Antimicrobial Resistance in P. aeruginosa}

P. aeruginosa, a ubiquitous organism with a relatively large genome and flexible metabolic capabilities, can exploit numerous environmental niches [35,36]. P. aeruginosa displays a formidable array of resistance mechanisms including efflux pumps, porin mutations and enzymes that confer resistance to $\beta$-lactam and aminoglycoside antibiotics [37-40]. Its intrinsic resistance to many antibiotics is largely due to the low permeability of its outer membrane, which limits drug penetration [41], and at least five families of efflux pumps that actively extrude antibiotics (e.g., MexA-MexB-OprM) have been identified in $P$. aeruginosa [42,43]. In addition, $P$. aeruginosa can acquire multiple resistance mechanisms through chromosomal gene mutations and horizontal transfer of mobile genetic elements, including plasmids, transposons, integrons, prophages and resistance islands, via conjugation, transformation or transduction $[41,43]$. In P. aeruginosa, horizontal gene transfer primarily affects aminoglycoside and $\beta$-lactam resistance but has been reported for other antibiotic classes, including fluoroquinolones [41,44-47]. P. aeruginosa biofilms are associated with persistent infections that are often recalcitrant to host defences and antibiotic therapy $[35,48]$. 
Although anti-pseudomonal $\beta$-lactams such as ceftazidime play an important part in treatment of P. aeruginosa infections, acquired $\beta$-lactamases in P. aeruginosa including ESBLs and carbapenemases can hydrolyse many $\beta$-lactams, including broad-spectrum cephalosporins and monobactams [49]. P. aeruginosa carries a chromosomal drug-inducible gene, ampC, which encodes AmpC, a broad-spectrum class C $\beta$-lactamase [50]. Wild-type P. aeruginosa typically express AmpC constitutively at low levels [38]. However, in the presence of an inducing $\beta$-lactam, AmpC expression may increase 100- to 1000 -fold, greatly increasing resistance to antipseudomonal penicillins (ticarcillin and piperacillin), monobactams (aztreonam) and third- (ceftazidime) and fourth-generation (cefepime) cephalosporins [50,51]. Regulation of ampC expression is controlled by three major gene products, namely an inner membrane permease (AmpG); a cytosolic amidase (AmpD); and a positive transcriptional regulator (AmpR), belonging to the LysR family [38]. Overproduction of AmpC is associated with mutations arising in $a m p G$, ampD and ampR [52,53]. Some P. aeruginosa isolates exhibit hyperproduction of the chromosomal $\beta$-lactamase caused by mutations in the regulatory circuit that controls the $\beta$-lactamase-inducible gene, ampC, and thus greatly increases the resistance to cephalosporins such as ceftazidime [50]. P. aeruginosa can also develop resistance to carbapenems through mutations down-regulating the expression of membrane porins, by upregulation of some efflux systems (e.g., MexAB-OprM) and through the acquisition of transferable genes encoding carbapenemases, such as MBLs (mostly VIM, IMP and occasionally NDM), KPCs and Guiana extended-spectrum (GES) enzymes [54,55].

For 2019, data from the European Antimicrobial Resistance Surveillance Network showed that $31.8 \%$ of $>20,000 P$. aeruginosa isolates from 30 European countries were resistant to at least one of five antimicrobial groups (piperacillin \pm tazobactam, fluoroquinolones, ceftazidime, aminoglycosides and carbapenems). Resistance to two or more antimicrobial groups was found in $17.6 \%$ of isolates, and $3.4 \%$ were resistant to all five antimicrobial groups [56]. These data showed encouraging population-weighted mean trends of declining overall P. aeruginosa resistance across Europe compared with previous years [56,57]; however, resistance rates vary substantially among countries, with high rates prevalent in eastern and southern countries.

In the US, the antimicrobial susceptibility of 7452 P. aeruginosa isolates collected from 79 medical centres in 2012-2015 was evaluated as part of the International Network for Optimal Resistance Monitoring (INFORM) programme [33]. MDR and XDR P. aeruginosa phenotypes were observed among $15.4 \%$ and $9.4 \%$ of isolates, respectively [33]. In China, the percentage of $P$. aeruginosa strains isolated from patients hospitalized in burn wards increased annually from $10.2 \%$ in 2007 to $26.2 \%$ in 2014, with this species becoming the predominant one among Gram-negative bacteria by 2014 [58]. Over the study period, the proportion of MDR P. aeruginosa increased from $64.0 \%$ in 2007 to $89.9 \%$ in 2014 [58].

\section{Treatment Guidelines for Management of P. aeruginosa Infections}

\subsection{Antibiotics for P. aeruginosa Infections}

Antimicrobial agents commonly used for the treatment of $P$. aeruginosa infections include intravenous (IV) $\beta$-lactams (such as anti-pseudomonal cephalosporins, carbapenems and $\beta$-lactam $/ \beta$-lactamase inhibitor combinations), fluoroquinolones and aminoglycosides, as well as polymyxins (colistin) in cases of last resort. Depending on the site and severity of infection, as well as the local resistance epidemiology, treatment guidelines for empiric and definitive antibiotic therapy of suspected or confirmed P. aeruginosa infections recommend various monotherapy or combination regimens using agents from the above classes (Table 1). Surgical source control is also recommended for patients with intra-abdominal infection (IAI). Some of the more recently published guidelines include guidance for use of ceftolozane-tazobactam and/or ceftazidime-avibactam for certain P. aeruginosa infections [59-63]. 
Table 1. Antimicrobial therapy recommendations for common P. aeruginosa infections.

\begin{tabular}{|c|c|c|c|}
\hline Guideline & $\begin{array}{c}\text { Clinical } \\
\text { Indication(s) }\end{array}$ & Antimicrobial Agent(s) & Recommendation(s) \\
\hline $\begin{array}{l}\text { European Association of Urology } \\
\text { (EAU), } 2018 \text { [59] }\end{array}$ & $\begin{array}{l}\text { cUTI, including } \\
\text { pyelonephritis } \\
\text { and urosepsis }\end{array}$ & $\begin{array}{c}\text { Ceftazidime } \\
\text { Cefepime } \\
\text { Piperacillin/tazobactam } \\
\text { Ceftolozane/tazobactam } \\
\text { Ceftazidime/avibactam } \\
\text { Gentamicin * } \\
\text { Amikacin * } \\
\text { Imipenem/cilastatin } \\
\text { Meropenem }\end{array}$ & $\begin{array}{l}\text { Treatment options for empirical antimicrobial } \\
\text { therapy. The choice between these agents } \\
\text { should be based on local resistance data, and } \\
\text { the regimen should be tailored on the basis of } \\
\text { susceptibility results. } \\
\text { Amoxicillin, co-amoxiclav, trimethoprim and } \\
\text { trimethoprim-sulphamethoxazole and } \\
\text { fluoroquinolones should not be used as } \\
\text { empiric treatment for urological patients. }\end{array}$ \\
\hline $\begin{array}{l}\text { British Society for Antimicrobial } \\
\text { Chemotherapy } \\
\text { (BSAC)/Healthcare Infection } \\
\text { Society (HIS)/British Infection } \\
\text { Association (BIA), 2018 [60] }\end{array}$ & UTI, IAI & $\begin{array}{c}\text { Ceftazidime } \\
\text { Piperacillin/tazobactam } \\
\text { Carbapenems (excluding } \\
\text { ertapenem) } \\
\text { Aminoglycosides } \\
\text { Fluoroquinolones } \\
\text { Ceftolozane/tazobactam }\end{array}$ & $\begin{array}{l}\text { Personalize empirical chemotherapy for each } \\
\text { patient by considering current features of } \\
\text { bacteraemia, risk factors for antibiotic } \\
\text { resistance and past susceptibility testing, } \\
\text { including the presence of MDR GNB in the } \\
\text { patient, hospital unit, nursing home or } \\
\text { community. } \\
\text { Do not use imipenem to treat susceptible } \\
\text { Pseudomonas infections. } \\
\text { Do not use ceftolozane/tazobactam for } \\
\text { infections due to AmpC- or CPE or } \\
\text { MBL/ESBL-producing P. aeruginosa. }\end{array}$ \\
\hline
\end{tabular}

\begin{tabular}{|c|c|c|c|}
\hline $\begin{array}{l}\text { World Society for Emergency } \\
\text { Surgery (WSES), } 2017 \text { [64] }\end{array}$ & cIAI & $\begin{array}{c}\text { Piperacillin/tazobactam } \\
\text { Imipenem/cilastatin } \\
\text { Doripenem } \\
\text { Ciprofloxacin/levofloxacin1 } \\
\text { Ceftazidime } \\
\text { Cefepime } \\
\text { Ceftazidime-avibactam } \\
\text { Ceftolozane-tazobactam } \\
\text { Amikacin } \\
\text { Gentamicin } \\
\text { Colistin }\end{array}$ & $\begin{array}{l}\text { In critically ill patients, antimicrobial therapy } \\
\text { should be started as soon as possible. } \\
\text { In these patients, to ensure timely and effective } \\
\text { administration of antibiotics, clinicians should } \\
\text { always consider the pathophysiological status } \\
\text { of the patient as well as the PK properties of } \\
\text { the employed } \\
\text { antibiotics. }\end{array}$ \\
\hline $\begin{array}{l}\text { Surgical Infection Society (SIS), } \\
2017 \text { [65] }\end{array}$ & cIAI & $\begin{array}{l}\text { Ceftolozane-tazobactam } \\
\text { Aminoglycosides } \\
\text { Polymyxin }\end{array}$ & $\begin{array}{c}\text { Empirical treatment options for patients with } \\
\text { risk factors for MDR, XDR or PDR } \\
\text { P. aeruginosa }( \pm \text { coverage for } \\
\text { Staphylococcus aureus }) \text {. }\end{array}$ \\
\hline $\begin{array}{l}\text { Spanish Society of Chemotherapy, } \\
2018 \text { [61] }\end{array}$ & $\begin{array}{l}\text { Acute invasive } \\
\text { infections }\end{array}$ & $\begin{array}{c}\text { Ceftolozane-tazobactam } \\
\text { Ceftazidime/avibactam } \\
\text { Meropenem } \\
\text { Ceftazidime } \\
\text { Piperacillin/tazobactam } \\
+ \\
\text { Amikacin, colistin or ciprofloxacin }\end{array}$ & $\begin{array}{l}\text { Include a } \beta \text {-lactam with activity against } \\
\text { P. aeruginosa with (a) the highest } \\
\text { probability to achieve the optimal value of the } \\
\text { adequate pharmacokinetic/pharmacodynamic } \\
\text { index, and (b) the lowest risk of } \\
\text { selection/amplification of the resistant } \\
\text { subpopulation. } \\
\text { For empirical treatment, consider combination } \\
\text { antibiotics during the first } 48-72 \mathrm{~h} \text { to rapidly } \\
\text { decrease the bacterial population, avoid } \\
\text { selection of resistance and } \\
\text { increase the probability of the strain to be } \\
\text { susceptible at least to one of the two } \\
\text { antibiotics. } \\
\text { For directed treatment schedules, consider } \\
\text { combination antibiotics if the infection } \\
\text { presents criteria for severe sepsis or septic } \\
\text { shock, in central nervous system } \\
\text { infections, in endocarditis or neutropenia and } \\
\text { when P. aeruginosa is resistant to } \\
\beta \text {-lactams. } \\
\text { Whatever antibiotic is chosen, it is essential to } \\
\text { optimize the dose and route of } \\
\text { administration. } \\
\text { Preferred treatment for patients with severe } \\
\text { sepsis/septic shock* and/or with risk factors } \\
\text { for MDR P. aeruginosa infections. }\end{array}$ \\
\hline
\end{tabular}


Table 1. Conts.

\begin{tabular}{|c|c|c|c|}
\hline Guideline & $\begin{array}{c}\text { Clinical } \\
\text { Indication(s) }\end{array}$ & Antimicrobial Agent(s) & Recommendation(s) \\
\hline \multirow[t]{2}{*}{$\begin{array}{l}\text { Infectious Diseases Society of } \\
\text { America (IDSA), } 2020 \text { [63] }\end{array}$} & $\begin{array}{l}\text { cUTI including } \\
\text { pyelonephritis }\end{array}$ & $\begin{array}{c}\text { Ceftolozane-tazobactam } \\
\text { Ceftazidime-avibactam } \\
\text { Imipenem-cilastatin-relebactam } \\
\text { Cefiderocol }\end{array}$ & $\begin{array}{l}\text { Preferred treatment options for pyelonephritis } \\
\text { and cUTI caused by DTR- } \\
\text { P. aeruginosa. }\end{array}$ \\
\hline & $\begin{array}{c}\text { DTR P. aeruginosa } \\
\text { infections outside the } \\
\text { urinary tract }\end{array}$ & $\begin{array}{l}\text { Ceftolozane-tazobactam } \\
\text { Ceftazidime-avibactam } \\
\text { Imipenem-cilastatin-relebactam }\end{array}$ & $\begin{array}{c}\text { Preferred treatment options (as monotherapy) } \\
\text { for the treatment of infections outside of the } \\
\text { urinary tract caused by DTR- } \\
\text { P. aeruginosa. }\end{array}$ \\
\hline $\begin{array}{c}\text { American Thoracic Society } \\
\text { (ATS)/Infectious Diseases Society } \\
\text { of America (IDSA), } 2016 \text { [66] }\end{array}$ & $\mathrm{HAP} / \mathrm{VAP}$ & $\begin{array}{c}\text { Piperacillin-tazobactam } \\
\text { Cefepime } \\
\text { Ceftazidime } \\
\text { Imipenem } \\
\text { Meropenem } \\
\text { Aztreonam } \\
\text { Fluoroquinolones } \\
\text { Aminoglycosides } \\
\text { Colistin }\end{array}$ & $\begin{array}{c}\text { Empiric regimens should cover for } \\
\text { S. aureus, P. aeruginosa and other } \\
\text { Gram-negative bacilli. } \\
\text { For patients with VAP or HAP with high } \\
\text { mortality risk, include two anti-pseudomonal } \\
\text { antibiotics from different classes. } \\
\text { In units where }>10 \% \text { of Gram-negative } \\
\text { isolates are resistant to an agent being } \\
\text { considered for monotherapy, and patients in } \\
\text { ICUs where local antimicrobial } \\
\text { susceptibility rates are unavailable }{ }^{\dagger} \text {. } \\
\text { Treat with two anti-pseudomonal agents of } \\
\text { different classes for patients with risk factors } \\
\text { for P. aeruginosa or other Gram-negative } \\
\text { infection or is at high risk of } \\
\text { mortality } \ddagger \text {. }\end{array}$ \\
\hline $\begin{array}{c}\text { European Respiratory Society } \\
\text { (ERS)/European Society of } \\
\text { Intensive Care Medicine } \\
\text { (ESICM)/European Society of } \\
\text { Clinical Microbiology and } \\
\text { Infectious Diseases } \\
\text { (ESCMID)/Latin American } \\
\text { Thoracic Association (ALAT), } \\
2017 \text { [67] }\end{array}$ & $\mathrm{HAP} / \mathrm{VAP}$ & $\begin{array}{c}\text { Cefepime } \\
\text { Ceftazidime } \\
\text { Piperacillin/tazobactam } \\
\text { Imipenem } \\
\text { Meropenem } \\
\text { Levofloxacin }\end{array}$ & $\begin{array}{c}\text { Consider a risk-stratification based approach; } \\
\text { all empiric therapy regimens for HAP/VAP } \\
\text { should include anti- } \\
\text { pseudomonal coverage. } \\
\text { Dual anti-pseudomonal antimicrobial } \\
\text { empiric therapy ( } \pm \text { coverage for S. aureus) } \\
\text { recommended for patients with septic shock } \\
\text { and in settings with high MDR pathogen risk. }\end{array}$ \\
\hline $\begin{array}{l}\text { UK National Institute for Health } \\
\text { and Care Excellence (NICE), } \\
2019 \text { [62] }\end{array}$ & $\mathrm{HAP} / \mathrm{VAP}$ & $\begin{array}{l}\text { Piperacillin/tazobactam } \\
\text { Anti-pseudomonal } \\
\text { cephalosporins } \\
\text { Meropenem } \\
\text { Ceftazidime-avibactam }\end{array}$ & $\begin{array}{c}\text { Treat with broad-spectrum empiric } \\
\text { Gram-negative coverage ( } \pm \text { coverage for } \\
\text { S. aureus }) \text {. }\end{array}$ \\
\hline $\begin{array}{c}\text { European Cystic Fibrosis Society } \\
\text { (ECFS), } 2018 \text { [68] }\end{array}$ & $\mathrm{CF}$ & $\begin{array}{l}\text { Tobramycin solution (or dry } \\
\text { powder) for inhalation } \\
\text { Aztreonam inhalation solution } \\
\text { Combination of nebulized colistin } \\
\text { and oral ciprofloxacin }\end{array}$ & $\begin{array}{c}\text { Treatment options for new and chronic } \\
\text { bronchopulmonary P. aeruginosa } \\
\text { infections. }\end{array}$ \\
\hline
\end{tabular}

* Severity criteria include criteria of severe sepsis or septic shock, severe immunodepression (especially neutropenia $<500$ cells $/$ mm $^{3}$ ) and infections involving high bacterial load, being not surgically controllable, such as extensive pneumonia or pneumonia with cavitations/necrosis. ${ }^{\dagger}$ For empirical antimicrobial therapy for patients with clinically suspected VAP. $\ddagger$ For empirical antimicrobial therapy for patients with clinically suspected HAP. CF, cystic fibrosis; cIAI, complicated intra-abdominal infection; cUTI, complicated urinary tract infection; DTR, difficult-to-treat resistance; HAP, hospital-acquired pneumonia; IAI, intra-abdominal infection; MDR, multidrug-resistant; PDR, pandrug-resistant; UTI, urinary tract infection; VAP, ventilator-associated pneumonia; XDR, extensively drug-resistant.

\subsection{Complicated Intra-Abdominal Infections}

The Surgical Infection Society guidelines for management of IAIs (2017) include stratification of empiric antimicrobial treatment recommendations based on the risk of pseudomonal involvement [65]. Third- or fourth-generation cephalosporins (e.g., cefotaxime, ceftriaxone, ceftizoxime, ceftazidime and cefepime) in combination with metronidazole, $\beta$-lactam/ $\beta$-lactamase inhibitors (e.g., piperacillin/tazobactam and ticarcillin/clavulanic acid) and carbapenems (e.g., meropenem and imipenem/cilastatin) are commonly used [69]. For patients with complicated IAI (cIAI) considered at risk for infection with MDR, XDR or pandrug-resistant $P$. aeruginosa, combinations of a $\beta$-lactam antibiotic, including ceftolozane-tazobactam, an aminoglycoside and/or a polymyxin are recommended [65]. 
The World Society for Emergency Surgery guidelines (2017) provide similar recommendations and, also recognize ceftolozane-tazobactam and ceftazidime-avibactam as approved treatments for cIAI caused by P. aeruginosa [64].

\subsection{Complicated Urinary Tract Infections}

The European Association of Urology (EAU) and the Dutch Working Party on Antibiotic Policy recommend antimicrobial treatment options for patients with complicated urinary tract infection (cUTI) that provide coverage against $P$. aeruginos $a$ and include amoxicillin plus an aminoglycoside, a second-generation cephalosporin plus an aminoglycoside or a third-generation cephalosporin [59,70]. A carbapenem with anti-pseudomonal activity (imipenem/meropenem) was recommended in 2013 for empiric therapy in patients with risk factors for ESBL infections [70]. The most recent EAU guidelines (2018) include recommendations for ceftazidime-avibactam and ceftolozane-tazobactam as empiric treatment options for pyelonephritis (second line) and urosepsis [59].

\subsection{Hospital-Acquired Pneumonia and Ventilator-Associated Pneumonia}

In patients with suspected VAP, the American Thoracic Society (ATS)/Infectious Diseases Society of America (IDSA) guidelines (2016) recommend coverage for Staphylococcus aureus, P. aeruginosa and other Gram-negative bacilli in all empiric regimens [66]. Combination therapy with two anti-pseudomonal antibiotics from two different classes is recommended in units where $>10 \%$ of Gram-negative isolates are resistant to an agent being considered for monotherapy, and patients in ICUs where local antimicrobial susceptibility rates are not available. For patients with hospital-acquired pneumonia (HAP) who are being treated empirically, ATS/IDSA guidelines recommend antibiotics with coverage against $P$. aeruginosa and other Gram-negative bacilli. If a patient has risk factors that increase the likelihood of P. aeruginosa or other Gram-negative infection (e.g., prior antimicrobials within 90 days), or is at high risk of mortality (e.g., need for ventilatory support due to HAP and septic shock), combination therapy with two anti-pseudomonal agents of different classes is recommended [66].

Similarly, international guidelines for management of patients with HAP/VAP (2017) published by the European Respiratory Society, European Society of Clinical Microbiology and Infectious Diseases, European Society of Intensive Care Medicine and Latin American Thoracic Association recommend a risk-stratification based approach, with dual anti-pseudomonal antimicrobial empiric therapy ( \pm coverage for $S$. aureus) for high-risk patients including those with septic shock and in settings with high MDR pathogen risk [67]. For patients with HAP/VAP and severe signs or symptoms, or those at higher risk of resistance, the UK National Institute for Health and Care Excellence guidelines (2019) do not specify dualantipseudomonal treatment but include broad-spectrum empiric Gram-negative coverage ( \pm coverage for $S$. aureus) with recommended agents including piperacillin/tazobactam, antipseudomonal cephalosporins, meropenem and ceftazidime-avibactam [62].

\subsection{Cystic Fibrosis}

The impaired mucociliary clearance in patients with CF provides a microenvironment in which pathogenic bacteria, including $P$. aeruginosa, can become the source of chronic pulmonary infections. The incidence of chronic P. aeruginosa infection in people with CF patients increases with age, and such individuals have worse health status and experience more rapid disease progression than age-matched controls [71]. The European Cystic Fibrosis Society recommendations for the management of new and chronic P. aeruginosa infections in patients with CF (2018) include tobramycin solution or dry powder for inhalation, aztreonam inhalation solution or a combination of nebulized colistimethate and oral ciprofloxacin; the aim of treatment should be eradication (documented by follow-up cultures) [68]. Acute exacerbations of pulmonary infections in patients with CF can result in hospitalization and require IV antibiotic treatment [68]. 


\section{Role of Ceftazidime-Avibactam in the Treatment of $P$. aeruginosa Infections 4.1. Approved Indications}

In Europe and the US, ceftazidime-avibactam is approved for the treatment of adults cUTI (including pyelonephritis), cIAI (in combination with metronidazole) and HAP (including VAP), including bacteraemia associated with these infections caused by susceptible P. aeruginosa and Enterobacterales. In Europe, it is also approved for infections caused by aerobic Gram-negative organisms in adult patients with limited treatment options. European and US approvals were recently extended to include paediatric patients $\geq 3$ months old (cUTI and cIAI indications only in the US) [72,73].

\subsection{Mechanism of Action}

$\beta$-lactams, including ceftazidime, exert antimicrobial effects through binding to penicillin binding proteins in bacterial cell walls, thereby disrupting cell wall synthesis and bacterial growth. As noted above, numerous antimicrobial resistance mechanisms can be expressed by MDR P. aeruginosa. Anti-pseudomonal cephalosporins such as ceftazidime, cefepime and ceftolozane have lower affinity for AmpC cephalosporinases (commonly expressed by $P$. aeruginosa) and additional stability against enzymatic hydrolysis than other cephalosporins $[74,75]$. However, susceptibility to these agents can be reduced by hyperexpression of AmpC. The addition of avibactam to ceftazidime overcomes AmpC cephalosporinase-mediated ceftazidime resistance among $P$. aeruginosa isolates in vitro (including those co-expressing EBSLs), but the combination is unable to overcome resistance mediated by porin mutations, efflux pumps or MBLs [76-79]. Moreover, alterations in AmpC-encoding and control genes conferring reduced susceptibility to ceftazidimeavibactam, ceftolozane/tazobactam and carbapenems have been reported in laboratory studies and/or identified in P. aeruginosa clinical isolates from patients undergoing antimicrobial therapy $[50,80-83]$. These findings are a salient reminder of the propensity of $P$. aeruginosa to undergo rapid evolution to develop novel resistance phenotypes and highlight the vital importance of microbiological cultures, susceptibility testing (as well as local and regional susceptibility patterns) and use of molecular diagnostics wherever possible to guide treatment of P. aeruginosa infections. In vitro data suggest that combining ceftazidime-avibactam with other antibiotics such as aminoglycosides or colistin may be synergistic against MDR P. aeruginosa [84-86].

\subsection{In Vitro Activity}

Numerous international and regional antimicrobial surveillance studies have reported on the in vitro activity of ceftazidime-avibactam using Clinical and Laboratory Standards Institute (CLSI) and European Committee on Antimicrobial Susceptibility Testing (EUCAST) interpretative criteria (also referred to as minimum inhibitory concentration (MIC) breakpoints), which define isolates of P. aeruginosa and Enterobacterales with ceftazidimeavibactam MICs $\leq 8 \mathrm{mg} / \mathrm{L}$ as susceptible $[87,88]$. Key susceptibility data for $P$. aeruginosa are summarized in Table 2.

Antimicrobial susceptibility testing was performed for ceftazidime-avibactam and comparator agents against 7062 clinical isolates of P. aeruginosa collected during 20122014 in four geographic regions (Europe, Asia/South Pacific, Latin America and Middle East/Africa) as part of the INFORM global surveillance study. The majority of isolates were susceptible (88.7-93.2\%) to ceftazidime-avibactam across the four regions (MIC 90 values of $8-16 \mathrm{mg} / \mathrm{L}$ ), in contrast to lower susceptibilities among comparator $\beta$-lactams: ceftazidime ( $\mathrm{MIC}_{90}, 32-64 \mathrm{mg} / \mathrm{L} ; 71.5-80.8 \%$ susceptible), meropenem (MIC $90,>8 \mathrm{mg} / \mathrm{L} ; 64.9-77.4 \%$ susceptible) and piperacillin-tazobactam ( $\mathrm{MIC}_{90},>128 \mathrm{mg} / \mathrm{L} ; 62.3-71.3 \%$ susceptible) [89]. 
Table 2. Overview of key in vitro studies of ceftazidime-avibactam activity against clinical isolates of P. aeruginosa.

\begin{tabular}{|c|c|c|c|c|c|c|c|c|}
\hline Study & Number of Isolates, Region and Study Dates & Isolate Source(s) & Agent & $\begin{array}{l}\text { MIC Range, } \\
\mathrm{mg} / \mathrm{L}\end{array}$ & $\begin{array}{l}\mathrm{MIC}_{50 \prime} \\
\mathrm{mg} / \mathrm{L}\end{array}$ & $\begin{array}{l}\mathrm{MIC}_{90}, \\
\mathrm{mg} / \mathrm{L}\end{array}$ & $\begin{array}{l}\text { Percentage } \\
\text { Susceptible, } \\
\%\end{array}$ & $\begin{array}{l}\text { Ceftazidime-Avibactam Resistance } \\
\text { Mechanisms }\end{array}$ \\
\hline $\begin{array}{l}\text { Nichols } \\
\text { et al. } \\
\text { (2016) [89] }\end{array}$ & $\begin{array}{l}7062 \\
\text { Asia/South Pacific, Europe, Latin America, Middle East/Africa } \\
\text { (2012-2014) }\end{array}$ & NR & $\begin{array}{l}\text { Ceftazidime- } \\
\text { avibactam }\end{array}$ & $\leq 0.5$ to $>128$ & 4 & 8 & 92.0 & $\begin{array}{c}\text { MBLs (VIM, IMP, NDM), serine } \\
\text { carbapenemases (KPC-2, GES) and ESBLs } \\
\text { (SHV-5, VEB, PER, GES ESBL-like, TEM-OSBL) }\end{array}$ \\
\hline \multirow{2}{*}{$\begin{array}{l}\text { Kazmierczak } \\
\text { et al. } \\
\text { (2016) [90] }\end{array}$} & \multirow{2}{*}{$\begin{array}{c}8010 \\
\text { Asia Pacific, } \\
\text { Europe, Latin/North America, Middle East/Africa 2012-2014) }\end{array}$} & \multirow{2}{*}{$\begin{array}{l}\text { Intra-abdominal, urinary tract, skin } \\
\text { and soft tissue, lower respiratory tract } \\
\text { and bloodstream infections }\end{array}$} & $\begin{array}{l}\text { Ceftazidime- } \\
\text { avibactam }\end{array}$ & 0.06 to $>128$ & 2 & 8 & 92.4 & \multirow[t]{2}{*}{ KPC-2, VIM-2, AmpC } \\
\hline & & & Ceftazidime & 0.06 to $>128$ & 2 & 64 & 77.4 & \\
\hline \multirow{2}{*}{$\begin{array}{l}\text { Kazmierczak } \\
\text { et al. } \\
\text { (2016) [90] }\end{array}$} & \multirow{2}{*}{$\begin{array}{c}29(\mathrm{KPC}- \\
\text { positive) } \\
\text { Asia Pacific, Latin America (2012-2014) }\end{array}$} & \multirow{2}{*}{$\begin{array}{l}\text { Intra-abdominal, urinary tract, skin } \\
\text { and soft tissue, lower respiratory tract } \\
\text { and bloodstream infections }\end{array}$} & $\begin{array}{l}\text { Ceftazidime- } \\
\text { avibactam }\end{array}$ & 4 to 64 & 8 & 32 & 75.9 & \multirow[t]{2}{*}{ KPC-2, VIM-2, AmpC } \\
\hline & & & Ceftazidime & 64 to 128 & 64 & $>128$ & 0.0 & \\
\hline \multirow[t]{2}{*}{$\begin{array}{l}\text { Sader et al. } \\
\text { (2017) [79] }\end{array}$} & \multirow[t]{2}{*}{$\begin{array}{c}7868 \\
\text { North America (2013-2016) }\end{array}$} & \multirow{2}{*}{$\begin{array}{l}\text { Intrabdominal, urinary tract, skin and } \\
\text { skin structure, pneumonia, } \\
\text { bloodstream and other infection types }\end{array}$} & $\begin{array}{l}\text { Ceftazidime- } \\
\text { avibactam }\end{array}$ & 0.25 to $>32$ & 2 & 4 & 97.1 & \multirow[t]{2}{*}{ NR } \\
\hline & & & Ceftazidime & NR & 2 & 32 & 84.7 & \\
\hline \multirow{2}{*}{$\begin{array}{l}\text { Sader et al. } \\
\text { (2017) [79] }\end{array}$} & \multirow{2}{*}{$\begin{array}{c}1562 \text { (MDR) } \\
\text { North America (2013-2016) }\end{array}$} & \multirow{2}{*}{$\begin{array}{l}\text { Intra-abdominal, urinary tract, skin } \\
\text { and skin structure, pneumonia, } \\
\text { bloodstream and other infection types }\end{array}$} & $\begin{array}{l}\text { Ceftazidime- } \\
\text { avibactam }\end{array}$ & 0.25 to $>32$ & 4 & 16 & 86.5 & \multirow[t]{2}{*}{ NR } \\
\hline & & & Ceftazidime & NR & 16 & $>32$ & 43.6 & \\
\hline $\begin{array}{l}\text { Sader et al. } \\
\text { (2017) [91] }\end{array}$ & $\begin{array}{c}3402 \\
\text { North America (2011-2015) }\end{array}$ & Pneumonia & $\begin{array}{l}\text { Ceftazidime- } \\
\text { avibactam }\end{array}$ & 0.25 to $>32$ & 2 & 4 & 96.6 & NR \\
\hline \multirow[t]{2}{*}{$\begin{array}{l}\text { Atkin } \\
\text { 2018 [92] }\end{array}$} & \multirow[t]{2}{*}{$\begin{array}{c}32 \\
\text { North America (2015) }\end{array}$} & \multirow[t]{2}{*}{ Cystic fibrosis } & $\begin{array}{l}\text { Ceftazidime- } \\
\text { avibactam }\end{array}$ & 0.5 to $>128$ & 4 & 64 & 71.9 & \multirow[t]{2}{*}{ OprD protein loss, AmpC, MexC MexX MexA } \\
\hline & & & Ceftazidime & 16 to $>128$ & 64 & $>128$ & 0.0 & \\
\hline \multirow{2}{*}{$\begin{array}{l}\text { Sader et al. } \\
\text { (2019) [93] }\end{array}$} & \multirow{2}{*}{$\begin{array}{c}2215 \\
\text { North America (2017-2018) }\end{array}$} & \multirow[t]{2}{*}{ Pneumonia } & $\begin{array}{l}\text { Ceftazidime- } \\
\text { avibactam }\end{array}$ & $\leq 0.015$ to $>32$ & 2 & 8 & 96.0 & \multirow[t]{2}{*}{ NR } \\
\hline & & & Ceftazidime & NR & 2 & 32 & 79.8 & \\
\hline \multirow[t]{2}{*}{$\begin{array}{l}\text { Sader et al. } \\
\text { (2019) [93] }\end{array}$} & \multirow[t]{2}{*}{$\begin{array}{c}526 \text { (MDR) } \\
\text { North America (2017-2018) }\end{array}$} & \multirow[t]{2}{*}{ Pneumonia } & $\begin{array}{l}\text { Ceftazidime- } \\
\text { avibactam }\end{array}$ & 0.06 to $>32$ & 4 & 16 & 83.5 & NR \\
\hline & & & Ceftazidime & NR & 32 & $>32$ & 32.3 & \\
\hline $\begin{array}{l}\text { Sid Ahmed } \\
\text { et al. } \\
\text { (2019) [94] }\end{array}$ & $\begin{array}{c}205 \text { (MDR) } \\
\text { Middle East (2014-2016) }\end{array}$ & $\begin{array}{l}\text { Respiratory tract, skin and soft tissue, } \\
\text { urinary tract, bloodstream, sterile } \\
\text { body fluids and vascular line tips }\end{array}$ & $\begin{array}{l}\text { Ceftazidime- } \\
\text { avibactam }\end{array}$ & $\leq 0.75$ to $>256$ & 4 & 64 & 68.8 & $\begin{array}{l}\text { MBLs (VIM-2 type) and ESBLs (VEB-1a, } \\
\text { OXA-4, OXA-10, OXA-50, TEM-116, PDC-2, } \\
\text { PDC-3, PDC-5 and PDC-7) }\end{array}$ \\
\hline
\end{tabular}

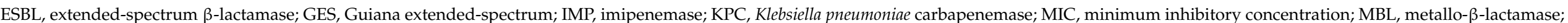

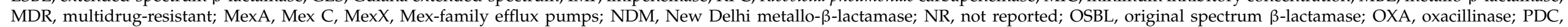

Pseudomonas-derived cephalosporinase; SHV, sulfhydryl variable; TEM, Timoniera; VEB, Vietnamese extended-spectrum $\beta$-lactamase; VIM, Verona integron-encoded metallo- $\beta$-lactamase. 
In an analysis of 11,185 Gram-negative isolates from hospitalized patients with pneumonia (including VAP) in 76 US medical centres between 2011 and 2015, ceftazidimeavibactam displayed good in vitro activity against 3402 P. aeruginosa isolates $\left(\mathrm{MIC}_{50} / \mathrm{MIC}_{90}\right.$, 2 and $4 \mathrm{mg} / \mathrm{L} ; 96.6 \%$ susceptible), including isolates non-susceptible to meropenem (86.3\% susceptible to ceftazidime-avibactam), piperacillin-tazobactam ( $85.6 \%$ susceptible) or ceftazidime (80.6\% susceptible). Other agents that were active against $P$. aeruginosa included colistin ( $\mathrm{MIC}_{50} / \mathrm{MIC}_{90}, 1$ and $2 \mathrm{mg} / \mathrm{L} ; 99.6 \%$ susceptible) and amikacin $\left(\mathrm{MIC}_{50} / \mathrm{MIC}_{90}, 4\right.$ and $16 \mathrm{mg} / \mathrm{L} ; 95.3 \%$ susceptible) [91].

Bacterial pathogens expressing KPC are clinically significant, as they frequently coexpress multiple other resistance mechanisms [90]. The gene encoding KPC (bla $a_{\mathrm{KPC}}$ ) has been observed in multiple Enterobacterales species and some non-fermentative Gramnegative pathogens, including P. aeruginosa [90]. Among 8010 P. aeruginosa isolates collected in 40 countries as part of the INFORM global surveillance study (2012-2014), 29 carbapenem-non-susceptible isolates carried $b l a_{\mathrm{KPC}}$ (K. pneumoniae was the most commonly isolated KPC-producing species). The majority of antimicrobial agents tested were inactive against 29 KPC-positive P. aeruginosa isolates (susceptibilities of $<4 \%$ ). However, $75.9 \%$ of these isolates were susceptible to ceftazidime-avibactam $\left(\mathrm{MIC}_{90}, 32 \mathrm{mg} / \mathrm{L}\right.$ ). Other agents that were active against KPC-positive P. aeruginosa included colistin ( $\mathrm{MIC}_{90}, 2 \mathrm{mg} / \mathrm{L}$; 96.6\% susceptible) and amikacin ( $\mathrm{MIC}_{90},>32 \mathrm{mg} / \mathrm{L} ; 75.9 \%$ susceptible) [90].

Similarly, against 7868 P. aeruginosa isolates from 94 US hospitals (2013-2016), ceftazidimeavibactam showed good in vitro activity ( $\mathrm{MIC}_{90}, 4 \mathrm{mg} / \mathrm{L} ; 97.1 \%$ susceptible), including against MDR isolates ( MIC $_{90}, 16 \mathrm{mg} / \mathrm{L} ; 86.5 \%$ susceptible) and inhibited (MIC $<8 \mathrm{mg} / \mathrm{L}$ ) $71.8 \%$ of 628 isolates that were non-susceptible to meropenem, piperacillin-tazobactam and ceftazidime [79].

Resistance mechanisms identified among P. aeruginosa isolates in the studies in Table 2 were predominantly enzymatic and included MBLs, serine carbapenemases (e.g., KPC-2 and GES) and ESBLs (e.g., SHV-5, VEB, PER and GES; Table 2); of note, non-enzymatic mechanisms, such as overexpression of efflux pumps and porin mutations, were not assessed in some studies $[89,90,94]$. In the 2012-2014 analysis, 563 of $7062(8 \%)$ P. aeruginosa isolates were resistant to ceftazidime-avibactam, of which 291 (51.7\%) were MBL-positive, 21 carried genes for serine carbapenemases (KPC-2 or GES type) \pm ESBLs, one isolate carried a GES of undefined activity, and 51 isolates harboured only ESBLs (SHV-5, VEB type, PER type or GES type); no acquired $\beta$-lactamase gene was identified in the remaining 199 ceftazidime-avibactam-resistant isolates [89]. Thus, approximately 271 non-MBLexpressing isolates expressed other unidentified resistance mechanisms that were not detected by PCR amplification and gene sequencing [89].

Analogous to ceftazidime-avibactam, ceftolozane-tazobactam, a $\beta$-lactam- $\beta$-lactamase inhibitor with in vitro activity against $P$. aeruginosa (including MDR isolates), is approved in Europe and the US for the treatment of adults with cUTI, cIAI and HAP/VAP $[95,96]$. Both ceftazidime-avibactam and ceftolozane-tazobactam have similar good activity against P. aeruginosa $[93,94,97]$. Other recently developed agents with activity against MDR P. aeruginosa (including some isolates resistant to ceftazidime-avibactam and ceftolozane-tazobactam) include cefiderocol, imipenem/cilastatin-relebactam and cefepime-zidebactam [98-100].

\subsection{Pharmacokinetics and Pharmacodynamics}

Population pharmacokinetic (PK) and pharmacodynamic (PD) analyses and probability of target attainment (PTA) simulations using an iterative modelling approach encompassing additional data at various points during clinical development supported the selection of doses for Phase 2 and 3 evaluation (including adjustments for renal impairment) and the determination of MIC susceptibility breakpoints for target pathogens, including P. aeruginosa [101-104].

For $\beta$-lactam antibiotics, the primary driver of PD is the amount of time free drug concentrations are maintained above the MIC of the target pathogen ( $\% f \mathrm{~T}>\mathrm{MIC})$. For ceftazidime, the $\beta$-lactam component of ceftazidime-avibactam, $50 \% f \mathrm{~T}>$ MIC is the established PK/PD target based on neutropenic mouse infection models and is associated with microbiological eradication in patients with Gram-negative infections [101]. In global 
surveillance studies, ceftazidime-avibactam $\mathrm{MIC}_{90}$ values of $\leq 8 \mathrm{mg} / \mathrm{L}$ were reported for phenotypically and genotypically unselected clinical isolates of $P$. aeruginosa [101]. Therefore, a target plasma concentration of $8 \mathrm{mg} / \mathrm{L}$ (i.e., matching the upper $\mathrm{MIC}_{90}$ value for target pathogens from contemporary surveillance studies) was selected for the ceftazidime component of the joint PK/PD target [101].

Based on in vitro hollow fibre and in vivo data, a PK/PD index for avibactam in combination with ceftazidime defined as percentage of time that free drug concentrations exceed a threshold concentration $\left(\mathrm{C}_{\mathrm{T}}\right)$ of $1 \mathrm{mg} / \mathrm{L}$ over a dose interval ( $\left.\% f \mathrm{~T}>\mathrm{CT}\right)$ (in combination with ceftazidime) was associated with bacteriostasis in a P. aeruginosa neutropenic mouse thigh infection model and 2- $\log _{10}$ killing in a P. aeruginosa neutropenic mouse lung infection model $[101,105,106]$. Accordingly, joint attainment of 50\% $f \mathrm{~T}>8 \mathrm{mg} / \mathrm{L}$ for ceftazidime and $50 \% f \mathrm{~T}>1 \mathrm{mg} / \mathrm{L}$ for avibactam, to be achieved simultaneously, was considered as the main PK/PD target for the PTA analyses.

The final population PK models, which included ceftazidime and avibactam PK data from eighteen Phase 1-3 clinical trials, were used to predict steady-state exposures and joint target attainment in the Phase 3 patient population and to conduct PTA analyses in simulated patients with cIAI, cUTI, nosocomial pneumonia and VAP, using the joint PK/PD target described above [102]. Ceftazidime and avibactam steady-state PK exposure parameters and joint target attainment rates were compared across a range of clinical scenarios, including the presence/absence of systemic inflammatory response syndrome, bacteraemia or fever, white blood cell count $\left(\leq 12,000 / \mathrm{mm}^{3}\right.$ or $\left.>12,000 / \mathrm{mm}^{3}\right)$ and various patient subgroups such as obesity, age, Acute Physiology and Chronic Health Evaluation II score and renal function categories (based on estimated creatinine clearance). With the exception of the 8-15 mL/min renal function group (which was limited by a small sample size of four patients), high joint target attainment rates ( $>93 \%)$ were attained for each indication in different clinical scenarios across patient subgroups [102].

PTA simulations using the final ceftazidime and avibactam population PK models were used to validate the approved ceftazidime-avibactam dosage regimen (2000 $\mathrm{mg}$ ceftazidime plus $500 \mathrm{mg}$ avibactam 2-h IV infusions every $8 \mathrm{~h}$ ), including adjustments for renal impairment. In these analyses, PTA values for target pathogens, including $P$. aeruginosa at MICs $\leq 8 \mathrm{mg} / \mathrm{L}$, were $95-100 \%$ across indications and renal function groups; lower PTA values were associated with MICs of 16 and $\geq 32 \mathrm{mg} / \mathrm{L}$ [102]. These analyses also supported the current EUCAST and CLSI susceptible MIC breakpoints of $\leq 8 \mathrm{mg} / \mathrm{L}$ for ceftazidime-avibactam against $P$. aeruginosa $[87,88,104]$. Separate analyses evaluating the lung penetration of ceftazidime-avibactam have demonstrated linear PK in epithelial lining fluid in mice and humans, with approved doses achieving clinically-relevant exposures against diverse P. aeruginosa isolates in an infection murine model [107-109].

\subsection{Ceftazidime-Avibactam in Clinical Trials}

Two Phase 2 and five Phase 3, randomized, multicentre active-comparator trials have evaluated the efficacy and safety of ceftazidime-avibactam against carbapenems/best available therapy in adults hospitalized with serious Gram-negative infections (Table 3). Each trial, which enrolled patients with cIAI, cUTI or HAP including VAP, included a treatment period (5-21 days) and primary efficacy evaluations at a protocol-defined test-of-cure (TOC) visit [110-116]. Apart from REPRISE, which did not use formal statistical comparisons, noninferiority of ceftazidime-avibactam versus the comparator treatment was demonstrated in the other four Phase III trials for their respective primary efficacy endpoints [112-116]. 
Table 3. Clinical cure and favourable microbiological response rates at TOC in Phase 2-3 clinical trials of ceftazidimeavibactam: patients with $P$. aeruginosa isolated at baseline.

\begin{tabular}{|c|c|c|c|c|}
\hline & \multicolumn{2}{|c|}{ Clinical Cure, n/N (\%) } & \multicolumn{2}{|c|}{$\begin{array}{l}\text { Favourable Microbiological } \\
\text { Response, n/N (\%) }\end{array}$} \\
\hline & $\begin{array}{l}\text { Ceftazidime- } \\
\text { Avibactam }\end{array}$ & Comparator * & $\begin{array}{l}\text { Ceftazidime- } \\
\text { Avibactam }\end{array}$ & Comparator * \\
\hline \multicolumn{5}{|l|}{ Phase 2 cIAI [110] } \\
\hline ME population & NR & NR & $5 / 5(100)$ & $5 / 5(100)$ \\
\hline \multicolumn{5}{|l|}{ Phase 2 cUTI [111] } \\
\hline ME population & NR & NR & $0 / 2(0)$ & $0 / 0$ \\
\hline \multicolumn{5}{|l|}{ Phase 3 RECLAIM 1 and 2: cIAI [112] } \\
\hline mMITT population & $30 / 35(85.7)$ & $34 / 36(94.4)$ & NR & NR \\
\hline \multicolumn{5}{|l|}{ Phase 3 RECLAIM 3: cIAI [114] } \\
\hline eME population & $11 / 11(100)$ & $12 / 14(85.7)$ & NR & NR \\
\hline \multicolumn{5}{|l|}{ Phase 3 REPRISE: cIAI and cUTI [113] } \\
\hline mMITT population: cIAI & $1 / 1(100)$ & $1 / 1(100)$ & NR & NR \\
\hline mMITT population: cUTI & $12 / 14(86.0)$ & $5 / 5(100)$ & $11 / 14(79.0)$ & $3 / 5(60.0)$ \\
\hline \multicolumn{5}{|l|}{ Phase 3 RECAPTURE 1 and 2: cUTI [115] } \\
\hline mMITT population & NR & NR & $12 / 18(66.7)$ & $15 / 20(75.0)$ \\
\hline \multicolumn{5}{|l|}{ Phase 3 REPROVE: HAP/VAP [116] } \\
\hline mMITT population & $22 / 39(56.4)$ & $19 / 26(73.1)$ & $22 / 58(37.9)$ & $18 / 47(38.3)$ \\
\hline ME population & $16 / 24(66.7)$ & 14/18 (77.8) & 13/31 (41.9) & $12 / 28(42.9)$ \\
\hline eME population & NR & NR & $18 / 42(42.9)$ & $14 / 35(40.0)$ \\
\hline CE population & $27 / 42(64.3)$ & $27 / 35$ (77.1) & NR & NR \\
\hline \multicolumn{5}{|l|}{$\begin{array}{c}\text { Pooled Phase } 3 \text { (all indications)-MDR } \\
\text { P. aeruginosa [117] }\end{array}$} \\
\hline mMITT population & NR & NR & $32 / 56(57.1)$ & $21 / 39(53.8)$ \\
\hline \multicolumn{5}{|l|}{$\begin{array}{c}\text { Pooled Phase } 3 \text { (all } \\
\text { indications) }-P . \text { aeruginosa bacteraemia [118] }\end{array}$} \\
\hline mMITT population & 11/15 (73.3) & 9/11 (81.8) & $10 / 15$ (66.7) & 7/11 (63.6) \\
\hline
\end{tabular}

* Comparator agents were meropenem for Phase 2 cIAI; REPROVE and RECLAIM and imipenem-cilastatin for Phase 2 cUTI; doripenem for RECAPTURE; and the best available therapy for REPRISE. CE, clinically evaluable; cIAI, complicated intra-abdominal infection; cUTI, complicated urinary tract infection; eME, extended microbiologically evaluable; HAP, hospital-acquired pneumonia; ME, microbiologically evaluable; mMITT, microbiologically modified intention-to-treat population; NR, not reported; TOC, test-of-cure visit; VAP, ventilatorassociated pneumonia. Clinical cure was defined as complete resolution or significant improvement of signs and symptoms of the index infection, with no further treatment required. Favourable microbiological response was defined as eradication/presumed eradication of original baseline pathogen(s).

Clinical and microbiological efficacy outcomes at TOC for the cohorts of patients with P. aeruginosa isolated at baseline in the Phase 2 and 3 adult trials are summarized in Table 3. Across the trials, ceftazidime-avibactam was generally effective in treating hospitalized adults with cUTI, cIAI and HAP/VAP caused by P. aeruginosa, as assessed by clinical cure and favourable microbiological response rates at the TOC visit [112-116]. In a pooled analysis of outcomes for patients with MDR Gram-negative isolates from the adult Phase 3 clinical trials, ceftazidime-avibactam demonstrated similar efficacy to comparators against MDR P. aeruginosa [117]. In the pooled microbiologically modified intention-to-treat (mMITT) population, a total of 56 patients in the ceftazidime-avibactam arm had MDR P. aeruginosa isolated at baseline. The ceftazidime-avibactam MIC range, $\mathrm{MIC}_{50}$ and $\mathrm{MIC}_{90}$ were 1 to $>256,8$ and $64 \mathrm{mg} / \mathrm{L}$, respectively, with $66.1 \%$ of isolates 
susceptible (MIC $\leq 8 \mathrm{mg} / \mathrm{L}$ ). Favourable microbiological responses at TOC (pooled mMITT population) were observed in 32 of 56 (57.1\%) patients in the ceftazidime-avibactam group and 21 of 39 patients $(53.8 \%)$ in the comparator group [117]. For patients with bacteraemia due to $P$. aeruginosa, a pooled analysis of the five Phase 3 trials found that clinical and microbiological responses were similar to those in the overall set; among bacteraemic patients with $P$. aeruginosa, the response rates were somewhat lower, but similar between treatment groups [118]. Across the Phase 3 trials, 28-day mortality rates were between $0 \%$ and $9.6 \%$ (per-pathogen mortality rates have not been reported). Decreased susceptibility of some microbiological isolates to study treatments was reported in the REPROVE trial; however, for P. aeruginosa, 10 patients in the meropenem group and none in the ceftazidimeavibactam group had isolates with decreased susceptibility [116].

\subsection{Real-World Experience}

A growing body of literature reporting on real-world use of ceftazidime-avibactam infections is available and has recently been reviewed [119]; available publications (as of August 2021) reporting outcomes of P. aeruginosa infections treated with ceftazidimeavibactam are summarized in Table 4 [120-131]. Several other publications report aggregated outcomes for cohorts of patients with infections caused by other pathogens as well as P. aeruginosa or Pseudomonas species [132-134]. Most of these studies are limited by generally small samples and retrospective, non-comparative, observational designs. However, these data provide important insights into the real-world therapeutic effectiveness of ceftazidime-avibactam in the treatment of often severely ill patients with complicated and difficult-to-treat infections.

In the largest real-world study with specific data for P. aeruginosa, Jorgensen et al. (2019) evaluated 203 patients treated with ceftazidime-avibactam for $\geq 72 \mathrm{~h}$ at six US hospitals (2015-2019) for various MDR Gram-negative infections [122]. P. aeruginosa were isolated from $63(31.0 \%)$ patients, and carbapenem-resistant Enterobacterales (CRE) from 117 (57.6\%). The most common infection sources for P. aeruginosa were respiratory tract $(60.3 \%)$, urinary tract $(11.1 \%)$, osteoarticular $(9.5 \%)$ and skin and soft tissue $(9.5 \%)$. Among patients with $P$. aeruginosa infections, clinical failure, 30-day mortality and 30-day recurrence were reported in $19(30.2 \%), 11(17.5 \%)$ and $4(6.3 \%)$ patients, respectively.

Vena et al. (2020) reported on the outcomes of ceftazidime-avibactam treatment for 41 patients admitted to 13 Italian hospitals with infections caused by non-CRE MDR Gram-negative bacteria, most commonly HAP (48.8\%), primary bacteraemia (17.1\%), IAI (9.8\%) and bone infections (9.8\%) [130]. Thirty-three patients $(80.5 \%)$ had monomicrobial $P$. aeruginosa infections and four patients $(9.8 \%$ ) had polymicrobial infections with P. aeruginosa and ESBL-positive Enterobacterales or Acinetobacter baumannii. Patients started ceftazidime-avibactam therapy subsequent to development of antimicrobial resistance to prior antibiotic therapy (61.0\%) or failure of prior antibiotic therapy (34.1\%) and median treatment duration was 13 days. Most patients $(80.5 \%)$ received ceftazidime-avibactam as combination therapy. Clinical cure was achieved in 29/33 (87.9\%) and 4/4 (100\%) of patients with monomicrobial and polymicrobial P. aeruginosa infections, respectively, and in 4/4 (100\%) of patients with monomicrobial ESBLproducing Enterobacterales infections. Development of resistance to ceftazidime-avibactam was not detected in any of 61 patients with repeat testing data available.

In another example of the efficacy of ceftazidime-avibactam in polymicrobial P. aeruginosa and Enterobacterales infections, Gofman et al. (2018) reported on a patient with polymicrobial ventriculitis caused by P. aeruginosa and carbapenem-resistant K. pneumoniae, who was successfully treated with ceftazidime-avibactam and intrathecal amikacin [121].

Santevecchi et al. (2018) evaluated 10 patients treated with ceftazidime-avibactam at a US hospital for non-K. pneumoniae infections during 2015-2016 [128]. Primary infections included pneumonia $(6 / 13 ; 46 \%)$, skin/soft tissue $(3 / 13 ; 23 \%)$, bacteraemia $(2 / 13 ; 15 \%)$ and IAI $(2 / 13 ; 15 \%)$; three patients were classified as having more than one infection. $P$. aeruginosa was the most commonly isolated organism (8 of 21 isolates). Five patients $(50 \%)$ received ceftazidime-avibactam monotherapy. Microbiological cure was achieved 
in $6 / 9$ evaluable patients (67\%) and clinical success in $7 / 10$ patients $(70 \%)$. Resistance emergence to ceftazidime-avibactam was reported in $2 / 10$ patients $(20 \%)$, one of whom was infected with P. aeruginosa.

Rodriguez-Nunez et al. (2018) evaluated outcomes for eight patients with infections caused by MDR or XDR P. aeruginosa admitted to a teaching hospital in Spain (20162017) treated with ceftazidime-avibactam for $\geq 72 \mathrm{~h}$ [127]. Infection sources were HAP in four patients $(50.0 \%)$ and tracheobronchitis, osteomyelitis, meningitis and catheterrelated bacteraemia in one patient each. The clinical cure rate was 50\%; 30-day and 90-day mortality rates were $13 \%$ and $38 \%$, respectively; no cases of ceftazidime-avibactam resistance emergence were reported.

Metafuni et al. (2019) and Xipell et al. (2017) have reported positive outcomes in individual patients with severe drug-resistant $P$. aeruginosa infections treated with ceftazidimeavibactam without documented emergence of resistance [126,131].

Spoletini et al. (2019) reported on eight adults with CF who received a total of 15 courses of ceftazidime-avibactam for pulmonary exacerbations not responding to conventional antibiotic treatment [129]. Four patients were colonized with P. aeruginosa, two with Burkholderia cepacia complex and two with both pathogens; and five were on the active waiting list for lung transplantation. Treatment with ceftazidime-avibactam was associated with an effective clinical response in 13 of $15(86.7 \%)$ treatment courses. Four of six patients with P. aeruginosa infections who had been suspended from the active transplant list were reactivated following clinical stabilization; one patient received a successful transplant while on treatment, and one who was on the transplant list died whilst on ceftazidime-avibactam due to respiratory failure. No cases of ceftazidime-avibactam resistance emergence were reported.

\section{Conclusions}

P. aeruginosa infections can be challenging to treat, as the species has limited intrinsic susceptibility to many antibiotics as well as great propensity to express further multiple resistance mechanisms through mutation and horizonal gene acquisition [41,42]. P. aeruginosa is relatively common in infections in healthcare settings, causing around $10-20 \%$ of skin, lower respiratory and urinary tract infections in hospitalized patients, and is particularly associated with severe and critical illness, such as in ICU and haematological patients. Patients with acute $P$. aeruginosa infections are at significantly greater risk of 30-day mortality when receiving inappropriate initial antimicrobial therapy (IAT) vs. those receiving appropriate IAT; however, selection of appropriate IAT in some settings and regions is challenged by increasing antimicrobial resistance, including MDR and DTR P. aeruginosa [135,136].

Ceftazidime-avibactam demonstrates good in vitro activity against $P$. aeruginosa relative to comparator $\beta$-lactam agents, aminoglycosides and fluoroquinolones [79,89-92,97], with susceptibility rates comparable to amikacin and ceftolozane-tazobactam [79,90,91,94,97]. Ceftazidime-avibactam is not active against MBL-producing pathogens, and P. aeruginosa is capable of expressing multiple resistance mechanisms (including MBLs) that render some isolates, particularly MDR strains, non-susceptible to ceftazidime-avibactam. Accordingly, as with all antimicrobials, ceftazidime-avibactam usage should be guided by local susceptibility patterns and microbiological/antibiogram data whenever possible. 
Table 4. Real-world experience with ceftazidime-avibactam in patients with $P$. aeruginosa infections.

\begin{tabular}{|c|c|c|c|c|c|}
\hline Study & $\begin{array}{c}\text { Patient } \\
\text { Characteristics }\end{array}$ & $\begin{array}{c}\text { Baseline } \\
\text { Pathogens } \\
\text { (Resistance Mechanisms) }\end{array}$ & $\begin{array}{l}\text { Ceftazidime- } \\
\text { Avibactam Dose } \\
\text { and Duration }\end{array}$ & $\begin{array}{c}\text { Concomitant Antibiotics, } \\
\text { n/N (\%) }\end{array}$ & Reported Outcomes \\
\hline Algwizani (2018) [120] & $\begin{array}{c}6 \text { male patients, } \\
\text { age } 15-87 \text { years } \\
2 / 6(33 \%) \text { patients had } \\
\text { bacteraemia }\end{array}$ & $\begin{array}{c}\text { CRPA }(n=3) \\
\text { CRKP }(n=3 ; 2 \text { with OXA- } 48 \\
1 \text { with NDM and OXA-48) }\end{array}$ & $\begin{array}{c}2.5 \mathrm{~g} \text { q8h, adjusted for renal } \\
\text { function } \\
\text { Range } 9-30 \text { days }\end{array}$ & $3 / 6(50 \%)$ & $\begin{array}{c}5 / 6(83 \%) \text { patients achieved } \\
\text { clinical and/or microbiological } \\
\text { cure, including } 3 / 3(100 \%) \text { with } \\
\text { CRPA infections. } \\
1 \text { patient }(17 \%) \text { died } 9 \text { days after } \\
\text { starting ceftazidime-avibactam } \\
\text { treatment (NDM and OXA- } 48 \mathrm{~K} \text {. } \\
\text { pneumoniae CLABSI and VAP). }\end{array}$ \\
\hline Gofman (2018) [121] & $\begin{array}{l}\text { 32-year-old male with } \\
\text { intracranial haemorrhage due } \\
\text { to traumatic injury; } \\
\text { ventriculitis and sepsis }\end{array}$ & $\begin{array}{l}\text { P. aeruginosa } \\
\text { CRKP } \\
\text { Streptococcus } \\
\text { viridans }\end{array}$ & $2.5 \mathrm{~g} \mathrm{q} 8 \mathrm{~h}, 6$ weeks & $1 / 1(100 \%)$ & $\begin{array}{l}\text { CSF cultures were sterile after } \\
3 \text { days' treatment with } \\
\text { ceftazidime-avibactam }+ \\
\text { intrathecal amikacin, with } \\
\text { treatment continued for } 4 \text { and } 6 \\
\text { weeks, respectively. The patient } \\
\text { did not experience any seizures or } \\
\text { neurological deficits and was } \\
\text { transferred to a long-term care } \\
\text { facility for rehabilitation. }\end{array}$ \\
\hline Jorgensen (2019) [122] & $\begin{array}{c}203 \text { patients who received } \\
\text { ceftazidime-avibactam for } \\
>72 \mathrm{~h} \text {, median age } 62 \text { years, } \\
62 \% \text { male } \\
22 / 203(11 \%) \text { patients had } \\
\text { bacteraemia }\end{array}$ & $\begin{array}{c}\text { CRE (58\%); Pseudomonas spp. } \\
(31 \%) \text {; others }(23 \%)\end{array}$ & $\begin{array}{l}\text { 92/203 patients }(45 \%) \\
\text { required } \\
\text { renal dose adjustments; } \\
\text { median duration } 9 \text { days }\end{array}$ & $\begin{array}{l}\text { 68/203 (34\%) overall } \\
\text { 20/63 (30\%) in patients with } \\
\text { Pseudomonas spp. infection }\end{array}$ & $\begin{array}{l}\text { Clinical failure occurred in } 59 / 203 \\
(29 \%) \text { patients overall and } 19 / 63 \\
(30 \%) \text { in patients with Pseudomonas } \\
\text { spp. Infection. } \\
\text { 30-day recurrence occurred in } \\
\text { 12/203 (6\%) patients overall and } \\
\text { 19/63 (6\%) in patients with } \\
\text { Pseudomonas spp. Infection. }\end{array}$ \\
\hline King (2016) [123] & $\begin{array}{c}10 \text { patients, mean age } 73 \\
\text { years, } 70 \% \text { male, } \\
\text { median CCI } 6 \\
1 / 10(10 \%) \text { patients had } \\
\text { bacteraemia }\end{array}$ & P. aeruginosa (MDR and XDR) & NR & $5 / 10(50 \%)$ & $\begin{array}{l}\text { Microbiological cure achieved in } \\
9 / 10(90 \%) \text { patients. } \\
\text { Clinical success achieved in } 8 / 10 \\
(80 \%) \text { patients. }\end{array}$ \\
\hline
\end{tabular}


Table 4. Conts.

\begin{tabular}{|c|c|c|c|c|c|}
\hline Study & $\begin{array}{c}\text { Patient } \\
\text { Characteristics }\end{array}$ & $\begin{array}{c}\text { Baseline } \\
\text { Pathogens } \\
\text { (Resistance Mechanisms) }\end{array}$ & $\begin{array}{l}\text { Ceftazidime- } \\
\text { Avibactam Dose } \\
\text { and Duration }\end{array}$ & $\begin{array}{l}\text { Concomitant Antibiotics, } \\
\text { n/N (\%) }\end{array}$ & Reported Outcomes \\
\hline Kuang (2020) [124] & $\begin{array}{c}20 \text { patients, mean age } 55 \\
\text { years, } 70 \% \text { male, mean CCI } 4 \\
7 / 20(35 \%) \text { patients had } \\
\text { bacteraemia }\end{array}$ & $\begin{array}{c}\text { K. pneumoniae }(n=18 ; \\
12 \text { CRKP }) \\
\text { P. aeruginosa } \\
\quad(n=3 ; \\
2 \text { carbapenem-resistant }) \\
\text { Escherichia coli }(n=3 ; \text { all } \\
\text { ESBL-producing strains) } \\
\text { Others }(n=9)\end{array}$ & $\begin{array}{l}\text { Standard dose, adjusted for } \\
\text { renal function, duration NR }\end{array}$ & $10 / 20(50 \%)$ & $\begin{array}{l}\text { Clinical cure and failure at } 30 \text { days } \\
\text { were achieved in } 9 \text { and } 11 \text { cases, } \\
\text { respectively, including } 2 / 3(66 \%) \text { of } \\
\text { the patients with } P \text {. aeruginosa } \\
\text { infection and } 1 / 3(33 \%) \text { of the } P \text {. } \\
\text { aeruginosa patients with HAP and } \\
\text { cIAI and septic shock; co-infected } \\
\text { with CRKP and E. coli (ESBL); and } \\
\text { treated with } \\
\text { ceftazidime-avibactam, tigecycline } \\
\text { and aztreonam died after } \\
3 \text { days of treatment. } \\
\text { Adverse effects reported in } 3 / 20 \\
(15 \%) \text { of patients. }\end{array}$ \\
\hline Meschiari (2020) [125] & $\begin{array}{c}3 \text { patients (age } 29-66 \text { years, } 2 \\
\text { male) with neurosurgical } \\
\text { infections } \\
\text { Patients } 1 \text { and } 3 \text { (both male) } \\
\text { were treated with } \\
\text { ceftazidime-avibactam } \\
\text { (patient } 1 \text { after switching } \\
\text { from } \\
\text { ceftolozane-tazobactam) }\end{array}$ & $\begin{array}{l}\text { XDR P. aeruginosa }(n=3) \\
\operatorname{KPC}-\operatorname{KP}(n=1)\end{array}$ & $\begin{array}{l}\text { Patient 1: } 2.5 \mathrm{~g} \text { q6h extended } \\
\text { infusion (off-label dose) } \\
\text { Patient 3: } 2.5 \mathrm{~g} \mathrm{q} 8 \mathrm{~h}\end{array}$ & $\begin{array}{l}\text { Patient 1: az-treonam } 2 \mathrm{~g} \mathrm{q} 6 \mathrm{~h} \\
\text { for } 6 \text { weeks } \\
\text { Patient 3: col-istin then } \\
\text { switch to az-treonam } 2 \mathrm{~g} \mathrm{q} 6 \mathrm{~h} \\
\text { for } 8 \text { weeks }\end{array}$ & $\begin{array}{c}\text { Both patients treated with } \\
\text { ceftazidime-avibactam achieved } \\
\text { complete resolution of vertebral } \\
\text { osteomyelitis by CT/MRI after } \\
60 \text { days. } \\
\text { Rectal swab performed for routine } \\
\text { screening at the end of treatment } \\
\text { (Patient } 3 \text { ) yielded XDR } \\
\text { P. aeruginosa with acquired } \\
\text { resistance to } \\
\text { ceftazidime-avibactam } \\
\text { (MIC }=16 \mathrm{mg} / \mathrm{L}) .\end{array}$ \\
\hline Metafuni (2019) [126] & $\begin{array}{c}3 \text { haematological patients } \\
\text { with neu-tropenia and } \\
\text { Gram-negative bac-teraemia, } \\
\text { ages 52-69 years, all male, } \\
\text { CCI = } 3\end{array}$ & $\begin{array}{c}\mathrm{KPC}-\mathrm{KP}(n=2) \\
\text { MDR } P . \text { aeruginosa }(n=1)\end{array}$ & $\begin{array}{l}2.5 \mathrm{~g} \text { q8h, add-ed to current } \\
\text { antibiotics combination } \\
\text { Median (range) } \\
15(12-16) \text { days }\end{array}$ & $3 / 3(100 \%)$ & $\begin{array}{c}\text { Clinical success: } 2 / 3(67 \%) \text { of } \\
\text { patients, including } 1 / 1(100 \%) \\
\text { patient with P. aeruginosa in-fection. }\end{array}$ \\
\hline
\end{tabular}


Table 4. Conts

\begin{tabular}{|c|c|c|c|c|c|}
\hline Study & $\begin{array}{c}\text { Patient } \\
\text { Characteristics }\end{array}$ & $\begin{array}{c}\text { Baseline } \\
\text { Pathogens } \\
\text { (Resistance Mechanisms) }\end{array}$ & $\begin{array}{l}\text { Ceftazidime- } \\
\text { Avibactam Dose } \\
\text { and Duration }\end{array}$ & $\begin{array}{c}\text { Concomitant Antibiotics, } \\
\text { n/N (\%) }\end{array}$ & Reported Outcomes \\
\hline $\begin{array}{l}\text { Rodríguez-Núñez } \\
\text { (2018) [127] }\end{array}$ & $\begin{array}{c}8 \text { patients, ages } 51-71 \text { years, } \\
88 \% \text { male } \\
1 / 8(13 \%) \text { patients had } \\
\text { bacteraemia }\end{array}$ & P. aeruginosa (MDR and XDR) & Dose NR, range 7-34 days & $6 / 8(75 \%)$ & $\begin{array}{c}\text { Clinical cure achieved in } 4 / 8(50 \%) \\
\text { of patients. } \\
\text { 30-day mortality: } 1 / 8(13 \%) . \\
\text { 90-day mortality: } 3 / 8(38 \%) . \\
\text { 1/8 }(13 \%) \text { of patients developed } \\
\text { encephalopathy that improved } \\
\text { with drug discontinuation. }\end{array}$ \\
\hline Santevecchi (2018) [128] & $\begin{array}{c}10 \text { patients, ages } 32-74 \text { years, } \\
50 \% \text { male } \\
8 \text { patients had renal } \\
\text { impairment, including } 4 \\
\text { undergoing CRRT }\end{array}$ & $\begin{array}{c}\text { MDR P. aeruginosa }(n=8) \\
\text { CRE }(n=9) \\
\text { Other }(n=4)\end{array}$ & $\begin{array}{l}\text { Doses } \mathrm{NR} \text {, ad-justed for } \\
\text { renal function } \\
\text { Median (range) } \\
16(4-50) \text { days }\end{array}$ & $5 / 10(50 \%)$ & $\begin{array}{c}\text { Clinical success: } 7 / 10(70 \%) \\
\text { patients, including } 7 / 8(88 \%) \\
\text { patients with } \text { P. aeruginosa infection } \\
\text { Microbiological cure: } 6 / 9(67 \%) \\
\text { patients, including } 6 / 8(75 \%) \\
\text { patients with } \text { P. aeruginosa infection } \\
\text { 2/10 patients }(20 \%) \text { developed } \\
\text { emergence of resistance while on } \\
\text { therapy with } \\
\text { ceftazidime-avibactam. }\end{array}$ \\
\hline Spoletini (2019) [129] & $\begin{array}{l}8 \text { patients with CF ( } 63 \% \\
\text { female, ages } 22-41 \text { years) } \\
\text { re-ceived } 15 \text { courses of } \\
\text { ceftazidime-avibactam } \\
\text { (1-4 courses/patient) }\end{array}$ & $\begin{array}{l}\text { MDR P. aeruginosa }(n=6) \\
\text { Other }(n=4)\end{array}$ & $\begin{array}{c}\text { Doses NR } \\
\text { Range 12-145 days }\end{array}$ & $8 / 8(100 \%)$ & $\begin{array}{l}\text { Effective clinical response seen in } \\
\text { 13/15 courses }(87 \%) \text {, in-cluding } \\
\text { 10/11 where } P \text {. aeruginosa was } \\
\text { identified in spu-tum. } \\
\text { 2/8 (25\%) of patients with a very } \\
\text { poor prognosis died ow-ing to } \\
\text { complex underlying } \\
\text { lung pathology. }\end{array}$ \\
\hline
\end{tabular}

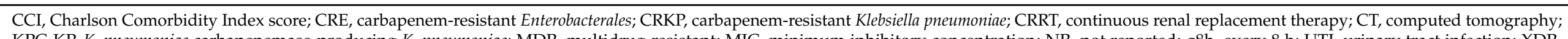

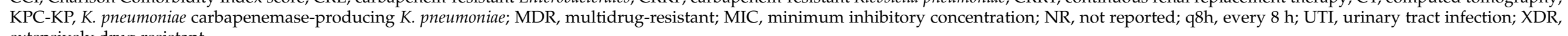
extensively drug-resistant. 
In Phase 3 clinical trials, ceftazidime-avibactam was associated with generally similar clinical and microbiological outcomes to comparators (carbapenems/best available therapy) in adult patients with cIAI, cUTI or HAP/VAP caused by P. aeruginosa, including ceftazidime non-susceptible and MDR strains [112-117]. In population PK modelling and exposure simulations of patients with cIAI, cUTI or HAP/VAP, >95\% PTA was predicted for approved ceftazidime-avibactam dosage regimens (2000 mg ceftazidime plus $500 \mathrm{mg}$ avibactam 2-h IV infusions every $8 \mathrm{~h}$, adjusted for renal function) against $P$. aeruginosa with MICs $\leq 8 \mathrm{mg} / \mathrm{L}$ [104]. While there are relatively few published real-world data for ceftazidime-avibactam treatment of serious P. aeruginosa infections, favourable outcomes with ceftazidime-avibactam treatment have been reported in some patients with infections caused by MDR and XDR P. aeruginosa, without documented resistance emergence (albeit from a small sample of anecdotal reports) [121,122,126-131]. The efficacy and safety of ceftazidime-avibactam in patients with CF have not been evaluated in randomized controlled trials; however, available in vitro and real-world data suggest a potential role for this agent in managing acute $P$. aeruginosa infections in cases where other antibiotics have failed [92,129], subject to local/institutional formularies and national product labelling.

As the risk factors for infections with different MDR bacteria, including P. aeruginosa and Enterobacterales, are often the same, ceftazidime-avibactam offers a good empiric treatment option for patients considered at risk of MDR Gram-negative infections, including those caused by non MBL-producing MDR and DTR P. aeruginosa, and its potential role in such settings is recognized in various national and international treatment guidelines [59,62-64]. Appropriate use of all antibiotics, including ceftazidime-avibactam, guided by diagnostic susceptibility data (where available) and knowledge of local resistance patterns, are vital to support antimicrobial stewardship and limit the emergence and spread of resistance.

Author Contributions: Conceptualization, N.B.-P., M.T., P.I.; data curation, G.L.D., C.A.d.C., G.M.R., G.G.S.; writing—original draft preparation, N.B.-P., M.T., P.I.; writing—review and editing, all authors. All authors critically reviewed the manuscript. All authors have read and agreed to the published version of the manuscript.

Funding: Medical writing support was funded by Pfizer.

Institutional Review Board Statement: Ethical approval is not applicable to this review article.

Informed Consent Statement: Informed consent is not applicable to this review article.

Data Availability Statement: No new data were created or analysed in this review article. Data sharing is not applicable to this article.

Acknowledgments: Medical writing support was provided by Atif Riaz and Mark Waterlow of Prime Medica Ltd., Knutsford, Cheshire, UK, and was funded by Pfizer.

Conflicts of Interest: G.L.D. reports grants and personal fees from Pfizer, personal fees from Achaogen, personal fees from MSD, personal fees from Rempex and personal fees from Menarini, outside the submitted work. C.A.d.C. reports grants and/or personal fees for international clinical trials, advisory boards, speaking and consultancies from Pfizer, Merck (MSD), Janssen Pharmaceuticals Inc. (Janssen Cilag), Novartis, Bayer, Eurofarma, Cerexa, GSK, Sanofi Aventis and AstraZeneca. G.M.R. has received research grants and/or been a consultant and/or received a fee for speaking from Achaogen, Arrow, Becton-Dickinson, bioMérieux, Checkpoints, Cubist, Curetis, Zambon, Basilea, Cepheid, Accelerate, Merck, Menarini, Nordic Pharma, Elitech, Qiagen, Angelini, Thermo Fisher, Biotest, Pfizer, Astra Zeneca, Rempex, Qpex, Roche, Seegene, Beckman Coulter, Shionogi, VenatorX and Nurex. P.I., G.G.S., N.B.-P. and M.T. are employees of and shareholders in Pfizer. 


\section{References}

1. Magill, S.S.; O'Leary, E.; Janelle, S.J.; Thompson, D.L.; Dumyati, G.; Nadle, J.; Wilson, L.E.; Kainer, M.A.; Lynfield, R.; Greissman, S.; et al. Emerging Infections Program Hospital Prevalence Survey Team. Changes in prevalence of health care-associated infections in U.S. hospitals. N. Engl. J. Med. 2018, 379, 1732-1744. [CrossRef]

2. Rhodes, N.J.; Cruce, C.E.; O'Donnell, J.N.; Wunderink, R.G.; Hauser, A.R. Resistance trends and treatment options in Gramnegative ventilator-associated pneumonia. Curr. Infect. Dis. Rep. 2018, 20, 3. [CrossRef] [PubMed]

3. Weiner, L.M.; Webb, A.K.; Limbago, B.; Dudeck, M.A.; Patel, J.; Kallen, A.J.; Edwards, J.R.; Sievert, D.M. Antimicrobial-resistant pathogens associated with healthcare-associated infections: Summary of data reported to the National Healthcare Safety Network at the Centers for Disease Control and Prevention, 2011-2014. Infect. Control Hosp. Epidemiol. 2016, 37, 1288-1301. [CrossRef] [PubMed]

4. Liu, J.Y.; Wu, Y.H.; Cai, M.; Zhou, C.L. Point-prevalence survey of healthcare-associated infections in Beijing, China: A survey and analysis in 2014. J. Hosp. Infect. 2016, 93, 271-279. [CrossRef] [PubMed]

5. Sadikot, R.T.; Blackwell, T.S.; Christman, J.W.; Prince, A.S. Pathogen-host interactions in Pseudomonas aeruginosa pneumonia. Am. J. Respir. Crit. Care Med. 2005, 171, 1209-1223. [CrossRef]

6. Markou, P.; Apidianakis, Y. Pathogenesis of intestinal Pseudomonas aeruginosa infection in patients with cancer. Front. Cell. Infect. Microbiol. 2014, 3, 115. [CrossRef]

7. Finnan, S.; Morrissey, J.P.; O'Gara, F.; Boyd, E.F. Genome diversity of Pseudomonas aeruginosa isolates from cystic fibrosis patients and the hospital environment. J. Clin. Microbiol. 2004, 42, 5783-5792. [CrossRef]

8. Tummler, B. Emerging therapies against infections with Pseudomonas aeruginosa. F1000Res. 2019, 8, F1000 Faculty Rev-1371. [CrossRef]

9. Babich, T.; Naucler, P.; Valik, J.K.; Giske, C.G.; Benito, N.; Cardona, R.; Rivera, A.; Pulcini, C.; Fattah, M.A.; Haquin, J.; et al. Risk factors for mortality among patients with Pseudomonas aeruginosa bacteraemia: A retrospective multicentre study. Int. J. Antimicrob. Agents 2019, 55, 105847. [CrossRef]

10. Lansbury, L.; Lim, B.; Baskaran, V.; Lim, W.S. Co-infections in people with COVID-19: A systematic review and meta-analysis. J. Infect. 2020, 81, 266-275. [CrossRef]

11. Ippolito, M.; Misseri, G.; Catalisano, G.; Marino, C.; Ingoglia, G.; Alessi, M.; Consiglio, E.; Gregoretti, C.; Giarratano, A.; Cortegiani, A. Ventilator-associated pneumonia in patients with covid-19: A systematic review and meta-analysis. Antibiotics 2021, 10, 545. [CrossRef]

12. Horcajada, J.P.; Montero, M.; Oliver, A.; Sorli, L.; Luque, S.; Gomez-Zorrilla, S.; Benito, N.; Grau, S. Epidemiology and treatment of multidrug-resistant and extensively drug-resistant Pseudomonas aeruginosa infections. Clin. Microbiol. Rev. 2019, 32, e00031-19. [CrossRef] [PubMed]

13. Moradali, M.F.; Ghods, S.; Rehm, B.H. Pseudomonas aeruginosa lifestyle: A paradigm for adaptation, survival, and persistence. Front. Cel.l Infect. Microbiol. 2017, 7, 39. [CrossRef] [PubMed]

14. Mulcahy, L.R.; Isabella, V.M.; Lewis, K. Pseudomonas aeruginosa biofilms in disease. Microb. Ecol. 2014, 68, 1-12. [CrossRef] [PubMed]

15. Carmeli, Y.; Troillet, N.; Eliopoulos, G.M.; Samore, M.H. Emergence of antibiotic-resistant Pseudomonas aeruginosa: Comparison of risks associated with different antipseudomonal agents. Antimicrob. Agents Chemother. 1999, 43, 1379-1382. [CrossRef]

16. Yusuf, E.; Van Herendael, B.; Verbrugghe, W.; Ieven, M.; Goovaerts, E.; Bergs, K.; Wouters, K.; Jorens, P.G.; Goossens, H. Emergence of antimicrobial resistance to Pseudomonas aeruginosa in the intensive care unit: Association with the duration of antibiotic exposure and mode of administration. Ann. Intensive Care 2017, 7, 1-7. [CrossRef] [PubMed]

17. Feng, Y.; Jonker, M.J.; Moustakas, I.; Brul, S.; Ter Kuile, B.H. Dynamics of mutations during development of resistance by Pseudomonas aeruginosa against five antibiotics. Antimicrob. Agents Chemother. 2016, 60, 4229-4236. [CrossRef]

18. Yayan, J.; Ghebremedhin, B.; Rasche, K. Antibiotic resistance of Pseudomonas aeruginosa in pneumonia at a single university hospital center in Germany over a 10-year period. PLoS ONE 2015, 10, e0139836. [CrossRef] [PubMed]

19. Canton, R.; Gijon, D.; Ruiz-Garbajosa, P. Antimicrobial resistance in ICUs: An update in the light of the COVID-19 pandemic. Curr. Opin. Crit. Care 2020, 26, 433-441. [CrossRef]

20. Miranda, C.; Silva, V.; Capita, R.; Alonso-Calleja, C.; Igrejas, G.; Poeta, P. Implications of antibiotics use during the COVID-19 pandemic: Present and future. J. Antimicrob. Chemother. 2020, 75, 3413-3416. [CrossRef]

21. Bassetti, M.; Vena, A.; Sepulcri, C.; Giacobbe, D.R.; Peghin, M. Treatment of bloodstream infections due to Gram-negative bacteria with difficult-to-treat resistance. Antibiotics. 2020, 9, 632. [CrossRef]

22. Kadri, S.S.; Adjemian, J.; Lai, Y.L.; Spaulding, A.B.; Ricotta, E.; Prevots, D.R.; Palmore, T.N.; Rhee, C.; Klompas, M.; Dekker, J.P.; et al. National Institutes of Health Antimicrobial Resistance Outcomes Research, I. Difficult-to-treat resistance in Gram-negative bacteremia at 173 US hospitals: Retrospective cohort analysis of prevalence, predictors, and outcome of resistance to all first-line agents. Clin. Infect. Dis. 2018, 67, 1803-1814. [PubMed]

23. Strich, J.R.; Warner, S.; Lai, Y.L.; Demirkale, C.Y.; Powers, J.H., 3rd; Danner, R.L.; Kadri, S.S. Needs assessment for novel Gram-negative antibiotics in US hospitals: A retrospective cohort study. Lancet Infect. Dis. 2020, 20, 1172-1181. [CrossRef]

24. Pang, Z.; Raudonis, R.; Glick, B.R.; Lin, T.J.; Cheng, Z. Antibiotic resistance in Pseudomonas aeruginosa: Mechanisms and alternative therapeutic strategies. Biotechnol. Adv. 2019, 37, 177-192. [CrossRef]

25. Zhanel, G.G.; Lawson, C.D.; Adam, H.; Schweizer, F.; Zelenitsky, S.; Lagace-Wiens, P.R.; Denisuik, A.; Rubinstein, E.; Gin, A.S.; Hoban, D.J.; et al. Ceftazidime-avibactam: A novel cephalosporin/beta-lactamase inhibitor combination. Drugs 2013, 73, 159-177. [CrossRef] [PubMed] 
26. Shirley, M. Ceftazidime-avibactam: A review in the treatment of serious Gram-negative bacterial infections. Drugs 2018, 78, 675-692. [CrossRef] [PubMed]

27. Falcone, M.; Paterson, D. Spotlight on ceftazidime/avibactam: A new option for MDR Gram-negative infections. J. Antimicrob. Chemother. 2016, 71, 2713-2722. [CrossRef] [PubMed]

28. Falcone, M.; Menichetti, F.; Cattaneo, D.; Tiseo, G.; Baldelli, S.; Galfo, V.; Leonildi, A.; Tagliaferri, E.; Di Paolo, A.; Pai, M.P. Pragmatic options for dose optimization of ceftazidime/avibactam with aztreonam in complex patients. J. Antimicrob. Chemother. 2021, 76, 1025-1031. [CrossRef]

29. Rains, C.P.; Bryson, H.M.; Peters, D.H. Ceftazidime. An update of its antibacterial activity, pharmacokinetic properties and therapeutic efficacy. Drugs 1995, 49, 577-617. [CrossRef] [PubMed]

30. Lagacé-Wiens, P.; Walkty, A.; Karlowsky, J.A. Ceftazidime-avibactam: An evidence-based review of its pharmacology and potential use in the treatment of Gram-negative bacterial infections. Core Evid. 2014, 9, 13-25. [CrossRef]

31. Stone, G.G.D.; Seifert, H.P.; Nord, C.E.P. In vitro activity of ceftazidime-avibactam against Gram-negative isolates collected in 18 European countries, 2015 to 2017. Int. J. Antimicrob. Agents 2020, 56, 106045. [CrossRef]

32. Sader, H.S.; Flamm, R.K.; Carvalhaes, C.G.; Castanheira, M. Antimicrobial susceptibility of Pseudomonas aeruginosa to ceftazidimeavibactam, ceftolozane-tazobactam, piperacillin-tazobactam, and meropenem stratified by U.S. Census Divisions: Results from the 2017 INFORM Program. Antimicrob. Agents Chemother. 2018, 62, e01587-18. [CrossRef] [PubMed]

33. Sader, H.S.; Huband, M.D.; Castanheira, M.; Flamm, R.K. Pseudomonas aeruginosa antimicrobial susceptibility results from four years (2012 to 2015) of the international network for optimal resistance monitoring program in the United States. Antimicrob. Agents Chemother. 2017, 61, e02252-16. [CrossRef]

34. Huband, M.D.; Castanheira, M.; Flamm, R.K.; Farrell, D.J.; Jones, R.N.; Sader, H.S. In vitro activity of ceftazidime-avibactam against contemporary pseudomonas aeruginosa isolates from U.S. medical centers by census region, 2014. Antimicrob. Agents Chemother. 2016, 60, 2537-2541. [CrossRef]

35. Mah, T.F.; Pitts, B.; Pellock, B.; Walker, G.C.; Stewart, P.S.; O’Toole, G.A. A genetic basis for Pseudomonas aeruginosa biofilm antibiotic resistance. Nature 2003, 426, 306-310. [CrossRef] [PubMed]

36. Kung, V.L.; Ozer, E.A.; Hauser, A.R. The accessory genome of Pseudomonas aeruginosa. Microbiol. Mol. Biol. Rev. 2010, 74, 621-641. [CrossRef]

37. Lopez-Causape, C.; Cabot, G.; Del Barrio-Tofino, E.; Oliver, A. The versatile mutational resistome of Pseudomonas aeruginosa. Front. Microbiol. 2018, 9, 685. [CrossRef]

38. Lister, P.D.; Wolter, D.J.; Hanson, N.D. Antibacterial-resistant Pseudomonas aeruginosa: Clinical impact and complex regulation of chromosomally encoded resistance mechanisms. Clin. Microbiol. Rev. 2009, 22, 582-610. [CrossRef]

39. Botelho, J.; Grosso, F.; Peixe, L. Antibiotic resistance in Pseudomonas aeruginosa-mechanisms, epidemiology and evolution. Drug Resist. Updat. 2019, 44, 100640. [CrossRef]

40. Rossolini, G.M.; Mantengoli, E. Treatment and control of severe infections caused by multiresistant Pseudomonas aeruginosa. Clin. Microbiol. Infect. 2005, 11, 17-32. [CrossRef]

41. Breidenstein, E.B.; de la Fuente-Nunez, C.; Hancock, R.E. Pseudomonas aeruginosa: All roads lead to resistance. Trends Microbiol. 2011, 19, 419-426. [CrossRef]

42. Wolter, D.J.; Lister, P. Mechanisms of $\beta$-lactam resistance among Pseudomonas aeruginosa. Curr. Pharm. Design. 2013, 19, 209-222. [CrossRef]

43. Eichenberger, E.M.; Thaden, J.T. Epidemiology and mechanisms of resistance of extensively drug resistant gram-negative bacteria. Antibiotics 2019, 8, 37. [CrossRef]

44. Del Barrio-Tofino, E.; Zamorano, L.; Cortes-Lara, S.; Lopez-Causape, C.; Sanchez-Diener, I.; Cabot, G.; Bou, G.; Martinez-Martinez, L.; Oliver, A.; GEMARA-SEIMC/REIPI Pseudomonas study Group. Spanish nationwide survey on Pseudomonas aeruginosa antimicrobial resistance mechanisms and epidemiology. J. Antimicrob. Chemother. 2019, 74, 1825-1835. [CrossRef]

45. Potron, A.; Poirel, L.; Nordmann, P. Emerging broad-spectrum resistance in Pseudomonas aeruginosa and Acinetobacter baumannii: Mechanisms and epidemiology. Int. J. Antimicrob. Agents 2015, 45, 568-585. [CrossRef]

46. Poirel, L.; Lambert, T.; Turkoglu, S.; Ronco, E.; Gaillard, J.; Nordmann, P. Characterization of Class 1 integrons from Pseudomonas aeruginosa that contain the bla(VIM-2) carbapenem-hydrolyzing beta-lactamase gene and of two novel aminoglycoside resistance gene cassettes. Antimicrob. Agents Chemother. 2001, 45, 546-552. [CrossRef] [PubMed]

47. Yan, J.J.; Hsueh, P.R.; Lu, J.J.; Chang, F.Y.; Ko, W.C.; Wu, J.J. Characterization of acquired beta-lactamases and their genetic support in multidrug-resistant Pseudomonas aeruginosa isolates in Taiwan: The prevalence of unusual integrons. J. Antimicrob. Chemother. 2006, 58, 530-536. [CrossRef]

48. Maurice, N.M.; Bedi, B.; Sadikot, R.T. Pseudomonas aeruginosa biofilms: Host response and clinical implications in lung infections. Am. J. Respir. Cell Mol. Biol. 2018, 58, 428-439. [CrossRef] [PubMed]

49. Juan, C.; Torrens, G.; Gonzalez-Nicolau, M.; Oliver, A. Diversity and regulation of intrinsic beta-lactamases from non-fermenting and other Gram-negative opportunistic pathogens. FEMS Microbiol. Rev. 2017, 41, 781-815. [CrossRef] [PubMed]

50. Berrazeg, M.; Jeannot, K.; Ntsogo Enguene, V.Y.; Broutin, I.; Loeffert, S.; Fournier, D.; Plesiat, P. Mutations in beta-lactamase AmpC increase resistance of Pseudomonas aeruginosa isolates to antipseudomonal cephalosporins. Antimicrob. Agents Chemother. 2015, 59, 6248-6255. [CrossRef] [PubMed] 
51. Lodge, J.M.; Piddock, L.J. The control of class I beta-lactamase expression in Enterobacteriaceae and Pseudomonas aeruginosa. J. Antimicrob. Chemother. 1991, 28, 167-172. [CrossRef]

52. Bagge, N.; Ciofu, O.; Hentzer, M.; Campbell, J.I.; Givskov, M.; Hoiby, N. Constitutive high expression of chromosomal betalactamase in Pseudomonas aeruginosa caused by a new insertion sequence (IS1669) located in ampD. Antimicrob. Agents Chemother. 2002, 46, 3406-3411. [CrossRef]

53. Zhang, Y.; Bao, Q.; Gagnon, L.A.; Huletsky, A.; Oliver, A.; Jin, S.; Langaee, T. ampG gene of Pseudomonas aeruginosa and its role in beta-lactamase expression. Antimicrob. Agents Chemother. 2010, 54, 4772-4779. [CrossRef]

54. Yin, S.; Chen, P.; You, B.; Zhang, Y.; Jiang, B.; Huang, G.; Yang, Z.; Chen, Y.; Chen, J.; Yuan, Z.; et al. Molecular typing and carbapenem resistance mechanisms of Pseudomonas aeruginosa isolated from a Chinese burn center from 2011 to 2016. Front. Microbiol. 2018, 9, 1135. [CrossRef]

55. Li, H.; Luo, Y.F.; Williams, B.J.; Blackwell, T.S.; Xie, C.M. Structure and function of OprD protein in Pseudomonas aeruginosa: From antibiotic resistance to novel therapies. Int. J. Med. Microbiol. 2012, 302, 63-68. [CrossRef] [PubMed]

56. European Centre for Disease Prevention and Control Antimicrobial Resistance in the EU/EEA (EARS-Net) -Annual Epidemiological Report for 2019. Available online: https:/ / www.ecdc.europa.eu/sites/default/files/documents/surveillance-antimicrobialresistance-Europe-2019.pdf (accessed on 6 September 2021).

57. European Centre for Disease Prevention and Control Surveillance of Antimicrobial Resistance in Europe. Annual report of the European Antimicrobial Resistance Surveillance Network (EARS-Net). 2018. Available online: https://www.ecdc.europa.eu/ sites/default/files/documents/surveillance-antimicrobial-resistance-Europe-2018.pdf (accessed on 6 September 2021).

58. Dou, Y.; Huan, J.; Guo, F.; Zhou, Z.; Shi, Y. Pseudomonas aeruginosa prevalence, antibiotic resistance and antimicrobial use in Chinese burn wards from 2007 to 2014. J. Int. Med. Res. 2017, 45, 1124-1137. [CrossRef]

59. European Association of Urology Guidelines on Urological Infections. Available online: https://uroweb.org/wp-content/ uploads/EAU-Guidelines-on-Urological-Infections-2018-large-text.pdf (accessed on 6 September 2021).

60. Hawkey, P.M.; Warren, R.E.; Livermore, D.M.; McNulty, C.A.M.; Enoch, D.A.; Otter, J.A.; Wilson, A.P.R. Treatment of infections caused by multidrug-resistant Gram-negative bacteria: Report of the British society for antimicrobial chemotherapy/healthcare infection society/british infection association joint working party. J. Antimicrob. Chemother. 2018, 73, iii2-iii78. [CrossRef]

61. Mensa, J.; Barberan, J.; Soriano, A.; Llinares, P.; Marco, F.; Canton, R.; Bou, G.; Gonzalez Del Castillo, J.; Maseda, E.; Azanza, J.R.; et al. Antibiotic selection in the treatment of acute invasive infections by Pseudomonas aeruginosa: Guidelines by the Spanish society of chemotherapy. Rev. Esp. Quimioter. 2018, 31, 78-100.

62. National Institute for Health and Care Excellence Pneumonia (Hospital-Acquired): Antimicrobial Prescribing. Available online: https: / / www.nice.org.uk/guidance/ng139 (accessed on 6 September 2021).

63. Tamma, P.D.; Aitken, S.L.; Bonomo, R.A.; Mathers, A.J.; van Duin, D.; Clancy, C.J. Infectious Diseases Society of America Antimicrobial Resistant Treatment Guidance: Gram-Negative Bacterial Infections. Available online: https://www.idsociety.org/ practice-guideline/amr-guidance/ (accessed on 6 September 2021).

64. Sartelli, M.; Chichom-Mefire, A.; Labricciosa, F.M.; Hardcastle, T.; Abu-Zidan, F.M.; Adesunkanmi, A.K.; Ansaloni, L.; Bala, M.; Balogh, Z.J.; Beltran, M.A.; et al. The management of intra-abdominal infections from a global perspective: 2017 WSES guidelines for management of intra-abdominal infections. World J. Emerg. Surg. 2017, 12, 29. [CrossRef]

65. Mazuski, J.E.; Tessier, J.M.; May, A.K.; Sawyer, R.G.; Nadler, E.P.; Rosengart, M.R.; Chang, P.K.; O'Neill, P.J.; Mollen, K.P.; Huston, J.M.; et al. The surgical infection society revised guidelines on the management of intra-abdominal infection. Surg. Infect. 2017, 18, 1-76. [CrossRef] [PubMed]

66. Kalil, A.C.; Metersky, M.L.; Klompas, M.; Muscedere, J.; Sweeney, D.A.; Palmer, L.B.; Napolitano, L.M.; O’Grady, N.P.; Bartlett, J.G.; Carratala, J.; et al. Management of adults with hospital-acquired and ventilator-associated pneumonia: 2016 Clinical Practice Guidelines by the Infectious Diseases Society of America and the American Thoracic Society. Clin. Infect. Dis. 2016, 63, e61-e111. [CrossRef] [PubMed]

67. Torres, A.; Niederman, M.S.; Chastre, J.; Ewig, S.; Fernandez-Vandellos, P.; Hanberger, H.; Kollef, M.; Li Bassi, G.; Luna, C.M.; Martin-Loeches, I.; et al. International ERS/ESICM/ESCMID/ALAT guidelines for the management of hospital-acquired pneumonia and ventilator-associated pneumonia: Guidelines for the management of hospital-acquired pneumonia (HAP)/ventilatorassociated pneumonia (VAP) of the European Respiratory Society (ERS), European Society of Intensive Care Medicine (ESICM), European Society of Clinical Microbiology and Infectious Diseases (ESCMID) and Asociacion Latinoamericana del Torax (ALAT). Eur. Respir. J. 2017, 50, 1700582. [PubMed]

68. Castellani, C.; Duff, A.J.A.; Bell, S.C.; Heijerman, H.G.M.; Munck, A.; Ratjen, F.; Sermet-Gaudelus, I.; Southern, K.W.; Barben, J.; Flume, P.A.; et al. ECFS best practice guidelines: The 2018 revision. J. Cyst. Fibros. 2018, 17, 153-178. [CrossRef]

69. Solomkin, J.S.; Mazuski, J.E.; Bradley, J.S.; Rodvold, K.A.; Goldstein, E.J.; Baron, E.J.; O’Neill, P.J.; Chow, A.W.; Dellinger, E.P.; Eachempati, S.R.; et al. Diagnosis and management of complicated intra-abdominal infection in adults and children: Guidelines by the Surgical Infection Society and the Infectious Diseases Society of America. Clin. Infect. Dis. 2010, 50, 133-164. [CrossRef]

70. Dutch Working Party on Antibiotic Policy SWAB Guidelines for Antimicrobial Therapy of Complicated Urinary Tract Infections in Adults. Available online: http:/ / swab.nl/exec/file/download/84 (accessed on 6 September 2021).

71. Parkins, M.D.; Somayaji, R.; Waters, V.J. Epidemiology, Biology, and Impact of Clonal Pseudomonas aeruginosa Infections in Cystic Fibrosis. Clin. Microbiol. Rev. 2018, 31, e00019-18. [CrossRef] 
72. Pfizer Summary of Product Characteristics: Zavicefta $2 \mathrm{~g} / 0.5 \mathrm{~g}$ Powder for Concentrate for Solution for Infusion. Available online: https:/ / www.ema.europa.eu/documents/product-information/zavicefta-epar-product-information_en.pdf (accessed on 6 September 2021).

73. Allergan AVYCAZ (Ceftazidime and Avibactam) for Injection, for Intravenous Use. Available online: https://www.allergan. com/assets/pdf/avycaz_pi (accessed on 6 September 2021).

74. Watanabe, N.A. Newer antipseudomonal cephalosporins. J. Chemother. 1996, 8, 48-56.

75. Zhanel, G.G.; Chung, P.; Adam, H.; Zelenitsky, S.; Denisuik, A.; Schweizer, F.; Lagace-Wiens, P.R.; Rubinstein, E.; Gin, A.S.; Walkty, A.; et al. Ceftolozane/tazobactam: A novel cephalosporin/beta-lactamase inhibitor combination with activity against multidrug-resistant gram-negative bacilli. Drugs 2014, 74, 31-51. [CrossRef]

76. Mushtaq, S.; Warner, M.; Livermore, D.M. In vitro activity of ceftazidime+NXL104 against Pseudomonas aeruginosa and other non-fermenters. J. Antimicrob. Chemother. 2010, 65, 2376-2381. [CrossRef]

77. Abboud, M.I.; Damblon, C.; Brem, J.; Smargiasso, N.; Mercuri, P.; Gilbert, B.; Rydzik, A.M.; Claridge, T.D.; Schofield, C.J.; Frere, J.M. Interaction of avibactam with class B metallo-beta-lactamases. Antimicrob. Agents Chemother. 2016, 60, 5655-5662. [CrossRef]

78. Buehrle, D.J.; Shields, R.K.; Chen, L.; Hao, B.; Press, E.G.; Alkrouk, A.; Potoski, B.A.; Kreiswirth, B.N.; Clancy, C.J.; Nguyen, M.H. Evaluation of the in vitro activity of ceftazidime-avibactam and ceftolozane-tazobactam against meropenem-resistant Pseudomonas aeruginosa isolates. Antimicrob. Agents Chemother. 2016, 60, 3227-3231. [CrossRef] [PubMed]

79. Sader, H.S.; Castanheira, M.; Shortridge, D.; Mendes, R.E.; Flamm, R.K. Antimicrobial activity of ceftazidime-avibactam tested against multidrug-resistant enterobacteriaceae and pseudomonas aeruginosa isolates from U.S. medical centers, 2013 to 2016. Antimicrob. Agents Chemother. 2017, 61, e01045-17. [CrossRef]

80. Lahiri, S.D.; Walkup, G.K.; Whiteaker, J.D.; Palmer, T.; McCormack, K.; Tanudra, M.A.; Nash, T.J.; Thresher, J.; Johnstone, M.R.; Hajec, L.; et al. Selection and molecular characterization of ceftazidime/avibactam-resistant mutants in Pseudomonas aeruginosa strains containing derepressed AmpC. J. Antimicrob. Chemother. 2015, 70, 1650-1658. [CrossRef]

81. Xu, C.; Wang, D.; Zhang, X.; Liu, H.; Zhu, G.; Wang, T.; Cheng, Z.; Wu, W.; Bai, F.; Jin, Y. Mechanisms for rapid evolution of carbapenem resistance in a clinical isolate of pseudomonas aeruginosa. Front. Microbiol. 2020, 11, 1390. [CrossRef]

82. Zamudio, R.; Hijazi, K.; Joshi, C.; Aitken, E.; Oggioni, M.R.; Gould, I.M. Phylogenetic analysis of resistance to ceftazidime/avibactam, ceftolozane/tazobactam and carbapenems in piperacillin/tazobactam-resistant Pseudomonas aeruginosa from cystic fibrosis patients. Int. J. Antimicrob. Agents 2019, 53, 774-780. [CrossRef] [PubMed]

83. Fraile-Ribot, P.A.; Cabot, G.; Mulet, X.; Perianez, L.; Martin-Pena, M.L.; Juan, C.; Perez, J.L.; Oliver, A. Mechanisms leading to in vivo ceftolozane/tazobactam resistance development during the treatment of infections caused by MDR Pseudomonas aeruginosa. J. Antimicrob. Chemother. 2018, 73, 658-663. [CrossRef] [PubMed]

84. Chen, T.; Xu, W.; Yu, K.; Zeng, W.; Xu, C.; Cao, J.; Zhou, T. In vitro activity of ceftazidime-avibactam alone and in combination with amikacin against colistin-resistant gram-negative pathogens. Microb. Drug Resist. 2021, 27, 401-409. [CrossRef]

85. Mikhail, S.; Singh, N.B.; Kebriaei, R.; Rice, S.A.; Stamper, K.C.; Castanheira, M.; Rybak, M.J. Evaluation of the synergy of ceftazidime-avibactam in combination with meropenem, amikacin, aztreonam, colistin, or fosfomycin against well-characterized multidrug-resistant Klebsiella pneumoniae and Pseudomonas aeruginosa. Antimicrob. Agents Chemother. 2019, 63, e00779-19. [CrossRef] [PubMed]

86. Mataraci Kara, E.; Yilmaz, M.; Istanbullu Tosun, A.; Ozbek Celik, B. Synergistic activities of ceftazidime-avibactam in combination with different antibiotics against colistin-nonsusceptible clinical strains of Pseudomonas aeruginosa. Infect. Dis. 2020, 52, 616-624. [CrossRef] [PubMed]

87. Clinical and Laboratory Standards Institute Performance Standards for Antimicrobial Susceptibility Testing, 30th Edition. CLSI Supplement M100. Available online: http:/ / em100.edaptivedocs.net/GetDoc.aspx?doc=CLSI\%20M100\%20ED30:2020 (accessed on 4 December 2020).

88. European Committee on Antimicrobial Susceptibility Testing Clinical Breakpoints for Bacteria, v 10.0. Available online: https: //www.eucast.org/fileadmin/src/media/PDFs/EUCAST_files/Breakpoint_tables/v_10.0_Breakpoint_Tables.pdf (accessed on 4 December 2020).

89. Nichols, W.W.; de Jonge, B.L.; Kazmierczak, K.M.; Karlowsky, J.A.; Sahm, D.F. In vitro susceptibility of global surveillance isolates of Pseudomonas aeruginosa to ceftazidime-avibactam (INFORM 2012 to 2014). Antimicrob. Agents Chemother. 2016, 60, 4743-4749. [CrossRef]

90. Kazmierczak, K.M.; Biedenbach, D.J.; Hackel, M.; Rabine, S.; de Jonge, B.L.; Bouchillon, S.K.; Sahm, D.F.; Bradford, P.A. Global dissemination of blaKPC into bacterial species beyond Klebsiella pneumoniae and in vitro susceptibility to ceftazidime-avibactam and aztreonam-avibactam. Antimicrob. Agents Chemother. 2016, 60, 4490-4500. [CrossRef] [PubMed]

91. Sader, H.S.; Castanheira, M.; Flamm, R.K. Antimicrobial activity of ceftazidime-avibactam against Gram-negative bacteria isolated from patients hospitalized with pneumonia in U.S. medical centers, 2011 to 2015. Antimicrob. Agents Chemother. 2017, 61, e02083-16. [CrossRef]

92. Atkin, S.D.; Abid, S.; Foster, M.; Bose, M.; Keller, A.; Hollaway, R.; Sader, H.S.; Greenberg, D.E.; Finklea, J.D.; Castanheira, M.; et al. Multidrug-resistant Pseudomonas aeruginosa from sputum of patients with cystic fibrosis demonstrates a high rate of susceptibility to ceftazidime-avibactam. Infect. Drug Resist. 2018, 11, 1499-1510. [CrossRef] [PubMed] 
93. Sader, H.S.; Flamm, R.K.; Carvalhaes, C.G.; Castanheira, M. Comparison of ceftazidime-avibactam and ceftolozane-tazobactam in vitro activities when tested against Gram-negative bacteria isolated from patients hospitalized with pneumonia in United States medical centers (2017-2018). Diagn. Microbiol. Infect. Dis. 2019, 96, 114833. [CrossRef] [PubMed]

94. Sid Ahmed, M.A.; Abdel Hadi, H.; Hassan, A.A.I.; Abu Jarir, S.; Al-Maslamani, M.A.; Eltai, N.O.; Dousa, K.M.; Hujer, A.M.; Sultan, A.A.; Soderquist, B.; et al. Evaluation of in vitro activity of ceftazidime/avibactam and ceftolozane/tazobactam against MDR Pseudomonas aeruginosa isolates from Qatar. J. Antimicrob. Chemother. 2019, 74, 3497-3504. [CrossRef]

95. Merck \& Co., Inc. ZERBAXA (Ceftolozane and Tazobactam) for Injection, for Intravenous Use. Available online: http:/ /www. merck.com/product/usa/pi_circulars/z/zerbaxa/zerbaxa_pi.pdf (accessed on 6 September 2021).

96. Merck Sharp \& Dohme Ltd. Zerbaxa $1 \mathrm{~g} / 0.5 \mathrm{~g}$ Powder for Concentrate for Solution for Infusion. Available online: https: //www.medicines.org.uk/emc/product/5009/smpc (accessed on 6 September 2021).

97. Humphries, R.M.; Hindler, J.A.; Wong-Beringer, A.; Miller, S.A. Activity of ceftolozane-tazobactam and ceftazidime-avibactam against beta-lactam-resistant Pseudomonas aeruginosa isolates. Antimicrob. Agents Chemother. 2017, 61, e01858-17. [CrossRef]

98. Delgado-Valverde, M.; Conejo, M.D.C.; Serrano, L.; Fernandez-Cuenca, F.; Pascual, A. Activity of cefiderocol against high-risk clones of multidrug-resistant Enterobacterales, Acinetobacter baumannii, Pseudomonas aeruginosa and Stenotrophomonas maltophilia. J. Antimicrob. Chemother. 2020, 75, 1840-1849. [CrossRef] [PubMed]

99. Fraile-Ribot, P.A.; Zamorano, L.; Orellana, R.; Del Barrio-Tofino, E.; Sanchez-Diener, I.; Cortes-Lara, S.; Lopez-Causape, C.; Cabot, G.; Bou, G.; Martinez-Martinez, L.; et al. Activity of imipenem-relebactam against a large collection of Pseudomonas aeruginosa clinical isolates and isogenic $\beta$-lactam-resistant mutants. Antimicrob. Agents Chemother. 2020, 64, e02165-19. [CrossRef]

100. Karlowsky, J.A.; Hackel, M.A.; Bouchillon, S.K.; Sahm, D.F. In vitro activity of WCK 5222 (Cefepime-zidebactam) against worldwide collected gram-negative bacilli not susceptible to carbapenems. Antimicrob. Agents Chemother. 2020, 64, e01432-20. [CrossRef]

101. Nichols, W.W.; Newell, P.; Critchley, I.A.; Riccobene, T.; Das, S. Avibactam pharmacokinetic/pharmacodynamic targets. Antimicrob. Agents Chemother. 2018, 62, e02446-17. [CrossRef] [PubMed]

102. Li, J.; Lovern, M.; Green, M.L.; Chiu, J.; Zhou, D.; Comisar, C.; Xiong, Y.; Hing, J.; MacPherson, M.; Wright, J.G.; et al. Ceftazidimeavibactam population pharmacokinetic modeling and pharmacodynamic target attainment across adult indications and patient subgroups. Clin. Transl. Sci. 2019, 12, 151-163. [CrossRef] [PubMed]

103. Das, S.; Li, J.; Riccobene, T.; Carrothers, T.J.; Newell, P.; Melnick, D.; Critchley, I.A.; Stone, G.G.; Nichols, W.W. Dose selection and validation for ceftazidime-avibactam in adults with complicated intra-abdominal infections, complicated urinary tract infections, and nosocomial pneumonia. Antimicrob. Agents Chemother. 2019, 63, e02187-18. [CrossRef]

104. Nichols, W.W.; Stone, G.G.; Newell, P.; Broadhurst, H.; Wardman, A.; MacPherson, M.; Yates, K.; Riccobene, T.; Critchley, I.A.; Das, S. Ceftazidime-avibactam susceptibility breakpoints against Enterobacteriaceae and Pseudomonas aeruginosa. Antimicrob. Agents Chemother. 2018, 62, e02590-17. [CrossRef]

105. Berkhout, J.; Melchers, M.J.; van Mil, A.C.; Seyedmousavi, S.; Lagarde, C.M.; Schuck, V.J.; Nichols, W.W.; Mouton, J.W. Pharmacodynamics of ceftazidime and avibactam in neutropenic mice with thigh or lung infection. Antimicrob. Agents Chemother. 2016, 60, 368-375. [CrossRef]

106. Coleman, K.; Levasseur, P.; Girard, A.M.; Borgonovi, M.; Miossec, C.; Merdjan, H.; Drusano, G.; Shlaes, D.; Nichols, W.W. Activities of ceftazidime and avibactam against beta-lactamase-producing Enterobacteriaceae in a hollow-fiber pharmacodynamic model. Antimicrob. Agents Chemother. 2014, 58, 3366-3372. [CrossRef]

107. Housman, S.T.; Crandon, J.L.; Nichols, W.W.; Nicolau, D.P. Efficacies of ceftazidime-avibactam and ceftazidime against Pseudomonas aeruginosa in a murine lung infection model. Antimicrob. Agents Chemother. 2014, 58, 1365-1371. [CrossRef] [PubMed]

108. Dimelow, R.; Wright, J.G.; MacPherson, M.; Newell, P.; Das, S. Population pharmacokinetic modelling of ceftazidime and avibactam in the plasma and epithelial lining fluid of healthy volunteers. Drugs R. D. 2018, 18, 221-230. [CrossRef] [PubMed]

109. Berkhout, J.; Melchers, M.J.; van Mil, A.C.; Seyedmousavi, S.; Lagarde, C.M.; Nichols, W.W.; Mouton, J.W. Pharmacokinetics and penetration of ceftazidime and avibactam into epithelial lining fluid in thigh- and lung-infected mice. Antimicrob. Agents Chemother. 2015, 59, 2299-2304. [CrossRef] [PubMed]

110. Lucasti, C.; Popescu, I.; Ramesh, M.K.; Lipka, J.; Sable, C. Comparative study of the efficacy and safety of ceftazidime/avibactam plus metronidazole versus meropenem in the treatment of complicated intra-abdominal infections in hospitalized adults: Results of a randomized, double-blind, Phase II trial. J. Antimicrob. Chemother. 2013, 68, 1183-1192. [CrossRef] [PubMed]

111. Vazquez, J.A.; Gonzalez Patzan, L.D.; Stricklin, D.; Duttaroy, D.D.; Kreidly, Z.; Lipka, J.; Sable, C. Efficacy and safety of ceftazidimeavibactam versus imipenem-cilastatin in the treatment of complicated urinary tract infections, including acute pyelonephritis, in hospitalized adults: Results of a prospective, investigator-blinded, randomized study. Curr. Med. Res. Opin. 2012, 28, $1921-1931$. [CrossRef]

112. Mazuski, J.E.; Gasink, L.B.; Armstrong, J.; Broadhurst, H.; Stone, G.G.; Rank, D.; Llorens, L.; Newell, P.; Pachl, J. Efficacy and safety of ceftazidime-avibactam plus metronidazole versus meropenem in the treatment of complicated intra-abdominal infection: Results from a randomized, controlled, double-blind, phase 3 program. Clin. Infect. Dis. 2016, 62, 1380-1389. [CrossRef]

113. Carmeli, Y.; Armstrong, J.; Laud, P.J.; Newell, P.; Stone, G.; Wardman, A.; Gasink, L.B. Ceftazidime-avibactam or best available therapy in patients with ceftazidime-resistant Enterobacteriaceae and Pseudomonas aeruginosa complicated urinary tract infections or complicated intra-abdominal infections (REPRISE): A randomised, pathogen-directed, phase 3 study. Lancet Infect. Dis. 2016, 16, 661-673. [PubMed] 
114. Qin, X.; Tran, B.G.; Kim, M.J.; Wang, L.; Nguyen, D.A.; Chen, Q.; Song, J.; Laud, P.J.; Stone, G.G.; Chow, J.W. A randomised, double-blind, phase 3 study comparing the efficacy and safety of ceftazidime/avibactam plus metronidazole versus meropenem for complicated intra-abdominal infections in hospitalised adults in Asia. Int. J. Antimicrob. Agents 2017, 49, 579-588. [CrossRef] [PubMed]

115. Wagenlehner, F.M.; Sobel, J.D.; Newell, P.; Armstrong, J.; Huang, X.; Stone, G.G.; Yates, K.; Gasink, L.B. Ceftazidime-avibactam versus doripenem for the treatment of complicated urinary tract infections, including acute pyelonephritis: RECAPTURE, a phase 3 randomized trial program. Clin. Infect. Dis. 2016, 63, 754-762. [CrossRef] [PubMed]

116. Torres, A.; Zhong, N.; Pachl, J.; Timsit, J.F.; Kollef, M.; Chen, Z.; Song, J.; Taylor, D.; Laud, P.J.; Stone, G.G.; et al. Ceftazidimeavibactam versus meropenem in nosocomial pneumonia, including ventilator-associated pneumonia (REPROVE): A randomised, double-blind, phase 3 non-inferiority trial. Lancet Infect. Dis. 2018, 18, 285-295. [CrossRef]

117. Stone, G.G.; Newell, P.; Gasink, L.B.; Broadhurst, H.; Wardman, A.; Yates, K.; Chen, Z.; Song, J.; Chow, J.W. Clinical activity of ceftazidime/avibactam against MDR Enterobacteriaceae and Pseudomonas aeruginosa: Pooled data from the ceftazidime/avibactam Phase III clinical trial programme. J. Antimicrob. Chemother. 2018, 73, 2519-2523. [CrossRef]

118. Mazuski, J.; Wagenlehner, F.; Torres, A.; Carmeli, Y.; Chow, J.W.; Wajsbrot, D.; Stone, G.G.; Irani, P.; Bharucha, D.; Cheng, K.; et al. Clinical and Microbiological Outcomes of Ceftazidime-Avibactam Treatment in Adults with Gram-Negative Bacteremia: A Subset Analysis from the Phase 3 Clinical Trial Program. Infect. Dis. Ther. 2021, in press. [CrossRef]

119. Soriano, A.; Carmeli, Y.; Omrani, A.S.; Moore, L.S.P.; Tawadrous, M.; Irani, P. Ceftazidime-Avibactam for the Treatment of Serious Gram-Negative Infections with Limited Treatment Options: A Systematic Literature Review. Infect. Dis. Ther. 2021, 1-46. [CrossRef]

120. Algwizani, A.; Alzunitan, M.; Alharbi, A.; Alsaedy, A.; Aljohani, S.; Alalwan, B.; Gramish, J.; Alothman, A. Experience with ceftazidime-avibactam treatment in a tertiary care center in Saudi Arabia. J. Infect. Public Health 2018, 11, 793-795. [CrossRef]

121. Gofman, N.; To, K.; Whitman, M.; Garcia-Morales, E. Successful treatment of ventriculitis caused by Pseudomonas aeruginosa and carbapenem-resistant Klebsiella pneumoniae with i.v. ceftazidime-avibactam and intrathecal amikacin. Am. J. Health Syst. Pharm. 2018, 75, 953-957. [CrossRef]

122. Jorgensen, S.C.J.; Trinh, T.D.; Zasowski, E.J.; Lagnf, A.M.; Bhatia, S.; Melvin, S.M.; Steed, M.E.; Simon, S.P.; Estrada, S.J.; Morrisette, T.; et al. Real-world experience with ceftazidime-avibactam for multidrug-resistant Gram-negative bacterial infections. In Open Forum Infectious Diseases; Oxford University Press: Oxford, UK, 2019; Volume 6, p. ofz522.

123. King, M.; Huang, V.; Gallagher, J.; Heil, E. Outcomes with ceftazidime/avibactam in patients with carbapenem-resistant pseudomonas infections: A multi-center study. In Open Forum Infectious Diseases; Oxford University Press: Oxford, UK, 2016; Volume 3.

124. Kuang, H.; Zhong, C.; Wang, Y.; Ye, H.; Ao, K.; Zong, Z.; Lv, X. Clinical characteristics and outcomes of patients with multidrugresistant Gram-negative bacterial infections treated with ceftazidime/avibactam. J. Glob. Antimicrob. Resist. 2020, 23, 404-407. [CrossRef]

125. Meschiari, M.; Franconi, I.; Bacca, E.; Bianco, V.; Orlando, G.; Cuomo, G.; Bedini, A.; Mussini, C. Ceftazidime/avibactam and ceftolozane/tazobactam for the treatment of extensively drug-resistant Pseudomonas aeruginosa post-neurosurgical infections: Three cases and a review of the literature. Infection 2020, 49, 549-553. [CrossRef] [PubMed]

126. Metafuni, E.; Criscuolo, M.; Spanu, T.; Sica, S. Ceftazidime-avibactam for Gram-negative multidrug-resistant bacteria in hematological patients: A single-center experience. Ann. Hematol. 2019, 98, 1495-1497. [CrossRef] [PubMed]

127. Rodriguez-Nunez, O.; Ripa, M.; Morata, L.; de la Calle, C.; Cardozo, C.; Feher, C.; Pellice, M.; Valcarcel, A.; Puerta-Alcalde, P.; Marco, F.; et al. Evaluation of ceftazidime/avibactam for serious infections due to multidrug-resistant and extensively drug-resistant Pseudomonas aeruginosa. J. Glob. Antimicrob. Resist. 2018, 15, 136-139. [CrossRef]

128. Santevecchi, B.A.; Smith, T.T.; MacVane, S.H. Clinical experience with ceftazidime/avibactam for treatment of antibiotic-resistant organisms other than Klebsiella pneumoniae. Int. J. Antimicrob. Agents 2018, 51, 629-635. [CrossRef] [PubMed]

129. Spoletini, G.; Etherington, C.; Shaw, N.; Clifton, I.J.; Denton, M.; Whitaker, P.; Peckham, D.G. Use of ceftazidime/avibactam for the treatment of MDR Pseudomonas aeruginosa and Burkholderia cepacia complex infections in cystic fibrosis: A case series. J. Antimicrob Chemother. 2019, 74, 1425-1429. [CrossRef]

130. Vena, A.; Giacobbe, D.R.; Castaldo, N.; Cattelan, A.; Mussini, C.; Luzzati, R.; Rosa, F.G.; Puente, F.D.; Mastroianni, C.M.; Cascio, A.; et al. Clinical experience with ceftazidime-avibactam for the treatment of infections due to multidrug-resistant Gram-negative bacteria other than carbapenem-resistant Enterobacterales. Antibiotics 2020, 9, 71. [CrossRef]

131. Xipell, M.; Bodro, M.; Marco, F.; Losno, R.A.; Cardozo, C.; Soriano, A. Clinical experience with ceftazidime/avibactam in patients with severe infections, including meningitis and lung abscesses, caused by extensively drug-resistant Pseudomonas aeruginosa. Int. J. Antimicrob. Agents 2017, 49, 266-268. [CrossRef]

132. Temkin, E.; Torre-Cisneros, J.; Beovic, B.; Benito, N.; Giannella, M.; Gilarranz, R.; Jeremiah, C.; Loeches, B.; Machuca, I.; Jimenez-Martin, M.J.; et al. Ceftazidime-avibactam as salvage therapy for infections caused by carbapenem-resistant organisms. Antimicrob. Agents Chemother. 2017, 61, e01964-16. [CrossRef]

133. Nwankwo, L.; Butt, Z.; Schelenz, S. Experience of Ceftazidime/avibactam in a UK tertiary cardiopulmonary specialist center. Expert Rev. Anti-Infect. Ther. 2021, 19, 101-108. [CrossRef]

134. Chen, W.; Sun, L.; Guo, L.; Cao, B.; Liu, Y.; Zhao, L.; Lu, B.; Li, B.; Chen, J.; Wang, C. Clinical outcomes of ceftazidime-avibactam in lung transplant recipients with infections caused by extensively drug-resistant gram-negative bacilli. Ann. Transl. Med. 2020, 8 , 39. [CrossRef] [PubMed] 
135. Morata, L.; Cobos-Trigueros, N.; Martinez, J.A.; Soriano, A.; Almela, M.; Marco, F.; Sterzik, H.; Nunez, R.; Hernandez, C.; Mensa, J. Influence of multidrug resistance and appropriate empirical therapy on the 30-day mortality rate of Pseudomonas aeruginosa bacteremia. Antimicrob. Agents Chemother. 2012, 56, 4833-4837. [CrossRef] [PubMed]

136. Martinez-Nadal, G.; Puerta-Alcalde, P.; Gudiol, C.; Cardozo, C.; Albasanz-Puig, A.; Marco, F.; Laporte-Amargos, J.; MorenoGarcia, E.; Domingo-Domenech, E.; Chumbita, M.; et al. Inappropriate empirical antibiotic treatment in high-risk neutropenic patients with bacteremia in the era of multidrug resistance. Clin. Infect. Dis. 2020, 70, 1068-1074. [CrossRef] [PubMed] 